University of Nebraska - Lincoln

DigitalCommons@University of Nebraska - Lincoln

USDA Wildlife Services - Staff Publications

U.S. Department of Agriculture: Animal and Plant Health Inspection Service

2010

\title{
Management of damage by elk (Cervus elaphus) in North America: a review
}

\author{
W. David Walter \\ National Wildlife Research Center, WDWalter@aphis.usda.gov \\ Michael J. Lavelle \\ USDA/APHIS/WS National Wildlife Research Center, michael.j.lavelle@aphis.usda.gov \\ Justin W. Fischer \\ USDA/APHIS/WS National Wildlife Research Center, Justin.w.fischer@aphis.usda.gov \\ Therese L. Johnson \\ Rocky Mountain National Park \\ Scott E. Hygnstrom \\ University of Nebraska-Lincoln, shygnstrom1@unl.edu
}

See next page for additional authors

Follow this and additional works at: https://digitalcommons.unl.edu/icwdm_usdanwrc

Part of the Life Sciences Commons

Walter, W. David; Lavelle, Michael J.; Fischer, Justin W.; Johnson, Therese L.; Hygnstrom, Scott E.; and Vercauteren, Kurt C., "Management of damage by elk (Cervus elaphus) in North America: a review" (2010). USDA Wildlife Services - Staff Publications. 1346.

https://digitalcommons.unl.edu/icwdm_usdanwrc/1346

This Article is brought to you for free and open access by the U.S. Department of Agriculture: Animal and Plant Health Inspection Service at DigitalCommons@University of Nebraska - Lincoln. It has been accepted for inclusion in USDA Wildlife Services - Staff Publications by an authorized administrator of DigitalCommons@University of Nebraska - Lincoln. 


\section{Authors}

W. David Walter, Michael J. Lavelle, Justin W. Fischer, Therese L. Johnson, Scott E. Hygnstrom, and Kurt C. Vercauteren 


\title{
Management of damage by elk (Cervus elaphus) in North America: a review
}

\author{
W. David Walter ${ }^{\mathrm{A}}$, Michael J. Lavelle ${ }^{\mathrm{A}}$, Justin W. Fischer ${ }^{\mathrm{A}}$, Therese L. Johnson ${ }^{\mathrm{B}}$, \\ Scott E. Hygnstrom ${ }^{\mathrm{C}}$ and Kurt C. VerCauteren ${ }^{\mathrm{A}, \mathrm{D}}$ \\ A United States Department of Agriculture, Animal and Plant Health Inspection Services, National Wildlife Research \\ Center, 4101 LaPorte Ave., Fort Collins, CO 80521, USA. \\ ${ }^{B}$ Rocky Mountain National Park, Estes Park, CO 80517, USA. \\ CUniversity of Nebraska, School of Natural Resources, 415 Hardin Hall, 3310 Holdrege Street, Lincoln, \\ NE 68583, USA. \\ ${ }^{D}$ Corresponding author. Email: Kurt.C.VerCauteren@aphis.usda.gov
}

\begin{abstract}
Abundant populations of elk (Cervus elaphus) are cherished game in many regions of the world and also cause considerable human-wildlife conflicts through depredation on agriculture and speciality crops, lack of regeneration to native ecosystems, collisions with vehicles and transmission of disease between free-ranging and farmed hoofstock. Management of elk varies, depending on current and historical agency objectives, configuration of the landscapes elk occupy, public perception, population density and behaviour of elk. Selection of the method to manage elk often requires knowledge of timing of impacts, duration relief from elk damage is desired, cost-effectiveness of management activities, tolerance of impacts, public perception of management strategies and motivation or habituation of elk to determine the likelihood of success for a proposed management action. We reviewed methods that are available to control abundant populations of elk that include lethal (e.g. hunting, sharpshooting) and non-lethal (e.g. fertility control, frightening) options. We promote an integrated approach that incorporates the timely use of a variety of cost-effective methods to reduce impacts to tolerable levels. Lethal options that include regulated hunting, sharpshooting and aerial gunning vary by likelihood of success, duration needed for population reduction, cost to implement reduction and public perceptions. Several non-lethal options are available to affect population dynamics directly (e.g. fertility control, translocation), protect resources from damage (e.g. fences, repellents) or influence space use of elk on a regular basis (e.g. harassment, frightening, herding dogs, humans). Public perception should be considered by agencies that are looking for feasible methods to control populations of elk. Disturbance to residents or visitors of public property may influence methods of management employed. Future research should explore the duration of harassment needed to avert elk from sensitive areas and costs to implement such programs. Several methods in our review were implemented on deer and additional research on elk and other cervids in conflict with human interests would provide a much needed component to our understanding of management methods available for ungulate species.
\end{abstract}

Additional keywords. Cervus elaphus, damage, ecosystem, elk, fence, fertility control, frightening, habituation, hazing, lethal, non-lethal, regeneration.

\section{Introduction}

Throughout the world, elk (Cervus elaphus) are a valuable commodity for generating revenue from hunting, wildlife viewing and farming (Bunnell et al. 2002; Peek et al. 2002; Donovan and Champ 2009). Considerable costs are expended, however, for supplemental feeding of elk to decrease winter mortality, increase antler size and increase size of populations for hunting and tourism in North America and Europe (Smith 2001; Putman and Staines 2004). Many agencies or provinces have instituted compensation programs for landowners that experience damage to hay bales or crops, often offsetting the negative impacts experienced by landowners from some populations of elk (Kessler 1995; Wagner et al. 1997). Populations of elk on public and private lands often provide considerable economic profit to landowners and outfitters for land access fees, guided hunts, and game processing, thus contributing revenue that was not available before the current population levels (Jordan and Workman 1989; Bunnell et al. 2002; Walter and Leslie 2002).

In contrast to all the economic, sociological and ecological benefit they provide, locally abundant populations of elk have caused substantial challenges for resource-management agencies throughout the world. Crop depredation (Hegel et al. 2009; Wilson et al. 2009), reduced regeneration of native aspen and willow stands (White et al. 1998; Brookshire et al. 2002), spread of disease (Brook and McLachlan 2006; Hamir et al. 2006), vehicle collisions and direct attacks by elk can affect entire ecosystems and human attitudes. Additional challenges arise on federal lands in the USA, with respect to practices such as providing supplemental feed to elk on the National Elk Refuge in 
Wyoming, USA (Dean et al.2004), or initiating natural regulation in Rocky Mountain National Park (ROMO), Colorado, USA (Johnson and Monello 2001). Reintroduction of elk onto Cyprus Hills Interprovincial Park in Canada has caused challenges with agricultural producers adjacent to the park boundary (Hegel et al. 2009) and supplemental feeding by private landowners in Europe causes conflicts with adjacent private landholders that desire lower densities of elk (Putman and Staines 2004). The resulting challenges and impacts on adjacent public and private lands further complicate management, constantly providing new and evolving challenges to resolve elk-human conflicts.

Establishment of elk populations in areas of extirpation over the past century also has caused considerable new elk-human conflicts for resource-management agencies, especially when elk disperse from areas of reintroduction (Stout et al. 1972; HernerThogmartin 1999; Maehr et al. 1999) because critical habitat and landscape configuration can influence reproduction, movements and the area of home ranges of cervids (McCorquodale 1991; Tufto et al. 1996; Relyea et al. 2000). The differences in the response (e.g. dispersal to adjacent states or territories) of elk in areas where they are restored could lead to new, unanticipated management challenges. Although conflicts with restored populations of elk is well documented, restorations of elk is occurring throughout North America, with many agencies proposing to restore populations of elk where they have been extirpated (Van Deelen et al. 1997; Didier and Porter 1999; Larkin et al. 2004; Rosatte et al. 2007). Elk have demonstrated fidelity to release sites in some areas, whereas at other sites, individuals have moved and dispersed depending on habitat characteristics of the release sites (Larkin et al. 2004; Rosatte et al. 2007).

Management of abundant populations of elk are often necessary to alleviate damage to native ecosystems, agricultural production and personal property, and for control of disease transmission. Several lethal and non-lethal techniques have been used to control the growth of elk populations, such as sustained harvest, fertility control and translocation (Hebblewhite et al. 2006; Frair et al. 2007; Killian et al.2009). Redistribution of local populations of elk has been attempted through habitat modification, hazing (defined as continual harassment by humans or humans with dogs or rubber projectiles until elk vacate the area), and repellents to prevent damage to sensitive habitats or conflicts with human interests (Baker et al. 1999; VerCauteren et al. 2005b, 2007b). Human encroachment into wildlife habitat and conflicting wildlife- and land-management policies often result in disparate management strategies for elk populations throughout their range. Perceptions, attitudes and actions of stakeholders undoubtedly will affect methods and policies used to address elk-human conflicts and protect ecosystems from abundant populations of elk. Here, we review (1) factors affecting elk-human conflicts, (2) the present state of knowledge of management methods to reduce impacts of elk and (3) research needs for this burgeoning problem currently facing resource agencies.

\section{Methods}

We used Google Scholar (http://scholar.google.com/, accessed 17 August 2009) and Internet Center for Wildlife Damage Management (http://icwdm.org/, accessed 17 August 2009) search engines and a web-based library (Digital Commons http://digitalcommons.unl.edu/, accessed 17 August 2009) to find germane scientific literature addressing conflicts with cervids, by using a combination of keywords (elk, deer, cervids, Cervus elaphus, Odocoileus spp., damage, depredation, agriculture, crops, competition, food habits, vertebrate, urban, suburban, residential, property, wapiti). We also searched the literaturecitation sections of relevant literature to determine secondary sources of information. Research on non-lethal techniques for elk specifically is lacking in some areas, so we relied on literature from research on other cervids, such as white-tailed deer (Odocoileus virginianus), to bolster non-lethal management options.

\section{Elk behaviour}

\section{Adaptability}

Elk is classified as a mixed-feeder because of their rumen size and ability to adapt to either a browsing or grazing diet (Mould and Robbins 1982; Hofmann 1988). Elk in the Great Plains of North America regularly consume diets high in grasses and forbs where deciduous trees and shrubs are less available (Fricke et al. 2008). Elk in the Pacific North-west consume varying amounts of deciduous and coniferous trees and shrubs, along with grasses and forbs, with quality and quantity varying seasonally (McCorquodale 1987; Jenkins and Starkey 1993; Beck and Peek 2005). Elk in western USA occupy vast open prairies, and can also feed on and decimate stands of aspen, willow and red alder, particularly during seasons of limited availability of natural forage (Baker and Hobbs 1982; Case and Kauffman 1997), causing reverse succession and favouring invasive and undesirable species. The ability of elk to exploit food resources of various quality and types has resulted in severe alteration of habitats (Suzuki et al. 1999; Dieni et al. 2000; Beschta and Ripple 2006).

Effective management actions of populations of elk influence densities and movements of elk, which, in turn, directly affect levels of browsing on select plant species (e.g. willow, Salix spp.) and regeneration of plant communities (Peinetti et al. 2002). Perceived impacts of elk on plant communities vary depending on the management objectives for elk populations and the status of land holdings (e.g. private, public; Burcham et al. 1999; Haggerty and Travis 2006; Neff 2007). Elk populations that occupy federal lands in Wyoming and Colorado where 'natural regulation' has been used in the past have decimated stands of native tree species (Coughenour and Singer 1996; Johnson and Monello 2001). Regeneration of trees has not been possible in some areas because populations of elk have increased and human alteration and urban sprawl into landscapes occupied by elk have either limited the availability of habitat or congregated elk on less suitable ranges (Burcham et al. 1999; Lubow et al. 2002; Haggerty and Travis 2006). Reintroduced populations of elk are often relegated to habitat deemed available, or to protected lands surrounded by fences, or within property boundaries that elk populations are expected to occupy (Walter and Leslie 2002; Larkin et al. 2004; Neff 2007). Although habitats occupied and forages consumed by elk vary by ecoregion, detrimental effects to plant communities often occur in areas where elk is supplied artificial feed, confined by fencing, have no 
natural predators, or are limited in their ability to roam and search for suitable forage (Clarke et al. 1994; Smith 2001; Peek et al. 2002; Hines et al. 2007). Herbivory on plants by more individuals and for longer durations and an increased risk of disease transmission can occur when abundant populations of ungulates are concentrated on ranges for long periods of time (Peinetti et al. 2002; Miller et al. 2003; Cross et al. 2010).

\section{Pre-European settlement regulation of populations}

Large predators and aboriginal peoples shaped the western ecosystems of North America before European settlement. Aboriginals were efficient predators that hunted cooperatively with other humans, dogs and fire, with no effective conservation practices (Kay 1994). Natural regulation of elk populations is likely to have never occurred in North America, with 1.2-3.5 million Native Americans present in North America at the time of Columbus's discovery (Kay 1994; McCabe 2002). Whereas aboriginals focused on harvesting mature elk individuals, large carnivores, such as wolves (Canis lupus) and grizzly bears (Ursus arctos), are likely to have reduced recruitment of elk populations through predation on calves (McCabe 2002). In addition to predation on young ungulates, wolves alter behaviour patterns, demographics and distribution of populations of elk (Hebblewhite and Pletscher 2002; Hebblewhite et al. 2002; Creel et al. 2005). In several states (e.g. Colorado), reintroduction of wolves has been considered to control the number and distribution of elk; however, biological (i.e. lack of enough suitable habitat) and sociological (i.e. fear of wolves, predation on livestock) conflicts have prevented such actions (Stewart et al. 2004; Licht et al. 2010).

\section{Elk-human conflicts}

\section{Depredation}

Agriculture is scattered throughout the range of elk and crop depredation by elk has been well documented (Oldenburg 1984; Van Tassell et al. 1999; Hygnstrom et al. 2005; Hegel et al. 2009). Elk individuals often search for agricultural crops, ornamental plantings and golf-course turf when natural forage is lacking (Kahler 1991; Brelsford et al. 1998; Hygnstrom et al. 2005). Elk are motivated to consume alternate forages such as wheat and alfalfa, because of selection for plants with high crude protein content $(>17 \%)$ and percentage protein digestibility $(>70 \%)$, compared with low crude protein content $(<10 \%)$ and percentage protein digestibility $(<48 \%)$ of common grass and browse species (Mould and Robbins 1981). Fields of agricultural crops are typically cultivated on private land and can be up to several hundreds of hectares in size. Limited hunting of elk on private land often results in refugia for populations of elk (Burcham et al. 1999; Hygnstrom et al. 2005). As natural forages senesce during late summer and winter, agriculture provides seasonal forage opportunities (e.g. winter wheat, waste grain) that are not available to elk in landscapes unaltered by agricultural practices. In some areas, densities of elk are elevated when, for example, row crops, stored hay bales, grain and silage are available, because this abundant food source can effectively increase the carrying capacity. These food sources (e.g. row crops) increase carrying capacity by providing additional quality forage that can sustain greater numbers of elk over the same area of the landscape, than would be present in natural settings (i.e. without human intervention).

\section{Pathogen transmission}

The effects of the proximity of artificial feed, agricultural fields and stored feed on domestic cattle operations have received considerable attention recently because of the association of disease with interactions between wildlife and domestic animals (Bienen and Tabor 2006; Etter and Drew 2006; Kilpatrick et al. 2009). Potential for transmission of chronic wasting disease (CWD), brucellosis (Brucella abortis) and bovine tuberculosis (Mycobacterium bovis) between freeranging elk and domestic animals (including farmed elk) has been well documented (Brook and McLachlan 2006; Etter and Drew 2006; Hamir et al. 2006; VerCauteren et al. 2007a). Disease has been associated with concentrated free-ranging wildlife in areas of artificial feed (Miller et al. 2003), stored feed (Daniels et al. 2003) or arable fields (Jay et al. 2007) because of increases in contact between wildlife and residual disease agents remaining in these areas. Temporary congregation of freeranging wildlife on concentrated food sources on winter range, either natural or provided by humans, has been found to influence disease prevalence in deer and elk (Van Deelen 2003; Farnsworth et al. 2005; Cross et al. 2007).

\section{Habituation}

Elk individuals that occupy remote landscapes that are free of routine human presence or disturbance, except during hunting seasons, typically flee when encountered by humans (Edge and Marcum 1985; Vieira et al. 2003; Storlie 2006). Elk can become accustomed or habituated to human presence. However, when humans are routinely in proximity but seldom harass elk or pose any threat, elk frequently adapt to passive human disturbance (e.g. feeding livestock, recreational activity; Cassirer et al. 1992; Thompson and Henderson 1998) and becomes difficult to manage with traditional techniques. Habituated elk individuals have been identified in residential communities (Thompson and Henderson 1998), national parks and refuges (Schultz and Bailey 1978; White et al. 1998), and near or around developed areas (e.g. ski-areas, wind turbines; Morrison et al. 1995; Walter et al. 2006). Habituation of elk to human presence and disturbance has been considered the driving force behind many elk-human conflicts in recent years (Thompson and Henderson 1998). Elk-vehicle collisions often result when elk are habituated to human activities in residential communities, parks and preserves, or in high-use travel corridors (Clevenger et al. 2001; Biggs et al. 2004; St Clair and Forrest 2009). Habituation by elk has lead to increased health and survival in urban/suburban landscapes through selection of optimal forage and a decrease in predation risk (McKenzie 2001; Rubin et al. 2002; Hebblewhite and Merrill 2009) and will continue as long as human encroachment into wildlife habitat occurs and there is a lack of concentrated efforts, lethal and non-lethal, to make elk view humans as a potential threat.

\section{Lethal options}

Lethal options are used to remove offending animals from the population and/or reduce the density of animals that are perceived 
to be overabundant (Kilpatrick et al. 1997; DeNicola and Williams 2008). The methods can be implemented to induce a relatively quick knockdown of the population (DeNicola and Williams 2008). Regulated or controlled hunting are considered to be cost-effective (Deblinger et al. 1993; Kilpatrick et al. 1997; Nugent and Choquenot 2004) and they can be integrated with non-lethal methods to increase their cost-effectiveness (DeNicola et al. 2000). The timing and method of lethal options are critical to maintain cost-effectiveness; however, some lethal options (e.g. sharpshooting, aerial gunning) may not be cost-effective because of the use of trained professionals and specialised equipment (Nugent and Choquenot 2004). Lethal options can be implemented across the landscape, as with regulated harvest or aerial gunning, whereas sharpshooting may be best implemented in very specific locations. Shooting can be highly selective for offending animals. Public acceptance of lethal options varies depending on location, species, experience with damage and moral convictions.

\section{Regulated harvest}

Recreational hunting is a primary tool used by wildlife agencies to control and, if needed, reduce the size of elk populations (Boyce 1989; Bunnell et al. 2002; Hegel et al. 2009). Hunting also provides extensive recreational opportunities, wildlifehabitat improvements, revenue generated from licence fees and hunter expenditures, job opportunities, and game meat for consumption (Boyce 1989; Jordan and Workman 1989; Cooper et al. 2002; Loveridge et al. 2006). Regulated harvest has been used successfully to control populations of white-tailed deer, mule deer (Odocoileus hemionus), elk and moose (Alces alces) by numerous agencies in open landscapes and fenced parks or preserves (Conner et al. 2001; Bunnell et al. 2002; Walter and Leslie 2002; Hams and Trindle 2008).

Conversely, lethal control in the form of hunting in some environments may be perceived as a threat to human safety, against local ordinances and may not be socially acceptable (Hansen and Beringer 1997; DeNicola et al. 2000; Lee and Miller 2003). The lack of regulated harvest or allowing natural regulation to control populations of ungulates often leads to abundant populations, damage to personal property, impacts on plant communities and other elk-human conflicts (Kay 1997; Bradford and Hobbs 2008; DeNicola et al. 2008). Abundant populations of elk were responsible for declines in aspen and willow communities in several national parks after natural regulation was initiated in the 1960s and harvest of elk was eliminated (Coughenour and Singer 1996; Peinetti et al. 2002). Recovery of sensitive plants and ecosystems has been documented after a significant reduction of ungulate populations was implemented by humans or natural predators (Deblinger et al. 1993; Kilpatrick et al. 2001; Ripple and Beschta 2003).

\section{Sharpshooting}

Sharpshooting by trained professionals with high-powered rifles, night vision and sound suppressors is an alternative to public hunting where the concern for public safety is high and lethal control is the desired management option (DeNicola et al. 2000; DeNicola and Williams 2008). Sharpshooting over bait sites or in areas where cervids congregate can provide a cost-effective means of reducing abundant deer or elk populations when regulated hunting is not an option (Lovaas 1973; DeNicola and Williams 2008). Ninety white-tailed deer individuals were removed in $27 \mathrm{~h}$ over bait in an urban community in New Hampshire, with no disturbance to the local community (DeNicola et al. 1997). If lethal methods of population control are warranted, sharpshooting is often preferred over hunting by local residents and the public in general (Chase and Decker 1998; Stewart et al. 2004).

\section{Aerial gunning}

Aerial gunning may be used to reduce populations of cervids to acceptable levels in remote areas or where cervids do not congregate (Hone 1990). Aerial gunning involves experienced shooters culling free-ranging wildlife from a helicopter and has been used on predators, feral hogs (Sus scrofa), red deer and Himalayan thar (Hemitragus jemlahicus; Smith et al. 1986; Dexter 1996; Parkes et al. 1996; Nugent and Choquenot 2004). Aerial gunning is often required in areas not easily accessible by terrestrial vehicles or where efficient removal of exotic species is needed to protect native ecosystems (Dexter 1996; Parkes et al. 1996). Public perception of this method has not been evaluated because aerial gunning is typically used in remote areas and not readily visible to the public.

\section{Capture and kill}

Techniques used to capture deer include rocket nets, drop-door box traps, drop nets, aerial net-gunning and chemical immobilisation (Ramsey 1968; Thompson et al. 1989; VerCauteren et al. 1997; DeNicola et al. 2000). In addition, elk can be captured in corral traps (Schemnitz 1994; Frair et al. 2007). Once captured, elk can be disposed of by lethal or nonlethal means. Animals that are killed must be killed as quickly and humanely as possible by using a gunshot to the head, captive bolt or chemical overdose (AVMA 2007). Because of inefficiency and the cost of capture and kill, this method is not recommended for use to control ungulate populations (DeNicola et al. 2000). Although this approach has been used for other cervids, we found no reference to its use on elk in the literature.

\section{Toxicants}

No information was found on the use of registered toxicants for controlling populations of elk in North America. Use of a toxic agent containing sodium monofluoroacetate (1080) was successful at killing up to $94 \%$ of a population of red deer in New Zealand, although high rainfall and high availability of alternate food sources limited effectiveness of 1080 for poisoning red deer in some locations (Nugent et al. 2001).

Lethal options of resolution of elk-human conflict can be time- and cost-efficient to implement (i.e. regulated hunting) or expensive and target specific animals in the population (i.e. capture and relocation, aerial gunning). Although cost and efficiency vary by method, lethal options provide immediate reduction of population size or remove individuals causing conflicts with humans. Lethal options can also be a precursor to non-lethal options that often rely on low elk densities to be successful. 


\section{Non-lethal options}

Most non-lethal techniques are designed to physically exclude offending animals or reduce the motivation of animals to access protected resources (Nolte 1999). Efficacy of exclusionary nonlethal techniques is directly correlated with the level of motivation of targeted individuals. Measures should be implemented to prevent cervids from exploiting a preferred resource before it is highly desired because dissuading cervids from using a resource is more difficult when motivation to gain access has increased (Spalinger et al. 1997; Nolte 1999; DeNicola et al. 2000; Gilsdorf et al. 2002, 2004b). For example, a simple frightening device employing sound and lights may be sufficient to deter use of a minimally desired resource for short periods, whereas a 1.8-m-high woven-wire mesh fence may be inadequate for keeping deer from a highly desired source of food. Management techniques chosen for a particular scenario under one level of motivation are likely to have a different degree of success in an alternate scenario. Thus, careful consideration of the level of motivation should help guide selection and implementation of any non-lethal technique.

Non-lethal tools such as fencing and frightening devices (e.g. scarecrows, noise makers) have been used for centuries. More recently, society has placed greater emphasis on the use of non-lethal techniques (e.g. fertility control), thus demonstrating the need for rigorous evaluation by resource agencies. Careful balancing of benefits and costs should be attempted to maintain positive net benefits of non-lethal actions (DeNicola et al. 2000). Unfortunately, in the absence of annual regulated hunting and ungulate-proof fencing in North America, most non-lethal approaches provide only temporary protection of resources and protect areas of relatively limited size (Witmer 1998; DeNicola et al. 2000). Because of limitations of non-lethal techniques, they should be part of an overall integrated management approach that includes lethal practices to maximise benefits. The focus of non-lethal control techniques, with no lethal component, should be on reducing damage to tolerable levels, as elimination of damage is unlikely (Gilsdorf et al. 2002). If some level of damage is expected and tolerable, however, non-lethal methods can be used to protect resources or harass wildlife to manage damage concerns (Stewart et al. 2004).

The public generally approves of non-lethal management techniques, especially in urban settings, where traditional hunting may not be safe and damage levels are high (DeNicola et al. 2000; Gilsdorf et al. 2002; Lauber et al. 2004). A recent survey of visitors to ROMO on acceptance of a variety of management techniques for alleviating habitat damage by a habituated population of elk revealed that several non-lethal options were acceptable (Stewart et al. 2004). The most socially acceptable methods included protecting individual trees with chicken wire, hazing with dogs and temporary fertility control (Stewart et al. 2004).

\section{Fertility control}

Fertility control includes several methods that can decrease reproduction in cervids, including, but not limited to, immunocontraceptives (Bradford and Hobbs 2006; Killian et al. 2009), intrauterine devices (Malcolm et al. 2010) and surgical procedures (MacLean et al. 2006). Modes of action of these fertility-control methods include sterilisation (steroid, castration, ovarectomy), contraception (steroid, intrauterine device, immunocontraception) and contragestation (steroid, terratogenic). Considerable effort has been expended to develop fertility-control agents and methods of delivery for cervids. Fertility-control agents for wildlife have the potential to be used in conjunction with lethal methods or scenarios where current lethal management techniques are ineffective or unacceptable (DeNicola et al. 2000; Malcolm et al. 2010). Initially, Knipling (1959) proposed the principle that undesirable wild-animal populations could be controlled with sterility-causing agents. Subsequently, Greer et al. (1968) fieldtested several methods on elk and the ensuing research was directed at the same goal, using an array of species and a variety of strategies. Early immunocontraceptives proved inefficient and expensive because they required a booster or a second shot (i.e. Walter et al. 2002).

Researchers have explored an array of chemical and immunological contraceptives for wildlife (Mauldin and Miller 2007). Recent developments in single-shot fertility-control methods have received considerable attention (Miller et al. 2009). Orally delivered contraceptives and live-vector (bacterial or viral) delivery have been explored; however, adequate ingestion of vaccine to result in decreased reproduction and Food and Drug Administration, which approves this technology in the United States, are limiting research (Miller et al. 1999; Fagerstone et al. 2002). Certain gonadotropin-releasing hormone (GnRH) agonists (e.g. leuprolide, deslorelin) have provided promising results in experimental captive (Baker et al. 2005) and free-ranging elk (Conner et al. 2007); however, efficacy was limited to a single breeding season, so animals must be treated annually. GonaCon (National Wildlife Research Center, Fort Collins, CO), a GnRH vaccine that temporarily produces infertility (deer and horses; Killian et al. 2006; Miller et al. 2008), recently received Environmental Protection Agency registration for use as a fertilitycontrol agent in white-tailed deer (L. A. Miller, USDA/APHIS/WS National Wildlife Research Center, pers. comm.). GonaCon has been effective in reducing fertility in captive elk (Killian et al. 2009) and potential for its use in managing free-ranging populations of elk in select settings, such as national parks, is currently being explored.

Remote injection of contraceptives annually to free-ranging populations of cervids is not feasible logistically and the cost is likely to be prohibitive (Walter et al. 2002). Currently, fertility control is not a viable strategy for managing free-ranging populations of cervids (Dolbeer 1998; DeNicola et al. 2000) beyond maintaining relatively small, closed populations (Rutberg et al. 2004). Further development in contraceptive technology (e.g. a single shot with multi-year efficacy) may result in more cost-effective contraceptives to assist in decreasing localised populations of elk to reduce elk-human conflicts.

\section{Capture and translocation}

In areas where overabundant wildlife negatively affects human health and safety and ecosystem function, capture and translocation may be a viable, non-lethal alternative. The capture methods are the same as those described previously. Translocation has been used to reduce urban and suburban 
populations of white-tailed deer where discharge of firearms was prohibited by municipal ordinances or local residents opposed lethal methods of removal (Cromwell et al. 1999; DeNicola et al. 2000; Beringer et al. 2002). Previous translocations were mainly used as a conservation tool for reintroducing elk into landscapes they historically occupied (O'Gara and Dundas 2002; Larkin et al. 2003, 2004).

Although public stakeholders commonly perceive capture and translocation as a humane method of population control (Ishmael et al. 1995), many concerns are associated with this technique. Problems include high cost (Ishmael and Rongstad 1984; O'Bryan and McCullough 1985; DeNicola et al. 2000), death resulting from capture myopathy (Beringer et al. 1996; Beringer et al. 2002), low rates of survival post-translocation (O'Bryan and McCullough 1985; Jones and Witham 1990), moving the problem from one area to another (Bryant and Ishmael 1991; Cromwell et al. 1999), and the potential to spread diseases and parasites (DeNicola et al. 2000; Hargreaves et al. 2004). All of these factors make it difficult to justify translocation as a feasible non-lethal method to address elk-human conflicts in North America.

\section{Repellents}

Repellents are non-lethal chemicals that theoretically decrease a plant's desirability or taste and therefore deter browsing and grazing by ungulates. Browsing can decrease crop yields, cause plant deformities and can be lethal to agricultural and forest plants (Nolte 1998). Among repellents, three different modes of action reduce herbivory, i.e. odour, contact and systemic. Odour repellents repel animals away from an area by using animal tissues (e.g. blood, rotten eggs) or predator odours (e.g. urine, faeces, hair) and are thought to elicit predatoravoidance behaviour (Mason 1998; Kimball et al. 2005). A plethora of research has been conducted on odour repellents used to reduce browse damage to plant resources by deer (Harris et al. 1983; Palmer et al. 1983; Conover 1984; Sayre and Richmond 1992) and, to a lesser extent, elk (Andelt et al. 1992; Baker et al. 1999). Active ingredients of odour repellents commonly contain ammonium soaps (Hygnstrom and Craven 1988; Andelt et al. 1994), putrescent whole-egg solids (Swihart and Conover 1990; Andelt et al. 1991, 1992), predator odours (Swihart et al. 1991; Andelt et al. 1992; Nolte et al. 2001) and human-food products (Andelt et al. 1994; Nolte et al. 1995; Seamans et al. 2002). Contact repellents are applied topically to targeted resources and immediately decrease plant palatability or induce negative post-ingestion consequences causing illness (aversive conditioning). Browse damage to plant resources by deer and elk has been alleviated with contact repellents that include capsaicin, which creates a 'hot' sensation when it comes to contact with mucous membranes (Harris et al. 1983; Palmer et al. 1983; Andelt et al. 1994; Baker et al. 1999). Others have demonstrated that bittering agents (e.g. denatonium benzoate; Harris et al. 1983; Swihart and Conover 1990; Andelt et al. 1991, 1992) and certain proteins (e.g. hydrolysed casein; Kimball et al. 2005; Kimball and Nolte 2006) reduce browsing of preferred forage. Systemic repellents are absorbed into plants by their roots and translocated to foliage by supplementation (e.g. selenium; Angradi and Tzilkowski 1987), or genetic manipulation
(Conover 2002), giving plants properties similar to those of contact repellents.

Many interacting factors determine efficacy of repellents and all repellents have a limited duration of success. Contact repellents may wash off or decompose; thus, repeated applications are necessary. As plants continue to grow, repellents need to be reapplied to new leaves or shoots. Andelt et al. (1992) speculated that food stress plays a major role in effectiveness of repellents. Thus, repellents are most effective when motivation (i.e. food stress) is low and alternative food sources are available. Regardless of repellent used, some damage to agricultural and forestry resources should be expected when using all repellents, even when conditions are optimal. Furthermore, the cost and practicality of using repellents, considering their limitations (e.g. duration of efficacy, size of the area to be treated), may require repellents to be used in conjunction with other methods (e.g. temporary fencing) to increase efficacy.

\section{Exclusion}

Fences provide an effective long-term, non-lethal technique to protect and minimise cervid damage. Fences provide protection in one of the following two ways: (1) as a physical barrier, (2) as a psychological barrier, or a combination of both. A typical 2.4-m-tall woven-wire fence is a physical barrier to cervids and greatly reduces the possibility of an animal passing over, under or through. Conversely, single- or double-strand electric poly-tape fences act as psychological barriers on the basis of learned avoidance conditioning (McKillop and Sibly 1988). Avoidance conditioning occurs when an animal contacts the fence, often with the nose or tongue, and receives a powerful electric shock. Training can be expedited by baiting the fence wire with peanut butter or molasses applied directly to the fence to create a negative stimuli when making contact with an electrified fence (Porter 1983; Hygnstrom and Craven 1988; Byrne 1989; J. W. Fischer, USDA/APHIS/WS National Wildlife Research Center, unpubl. data).

Fences for elk and deer have been rigorously tested and a substantial amount of research has been conducted and collated in a review by VerCauteren et al. (2006b). Broad classes of fence designs include woven-wire mesh, modified woven-wire mesh, high-tensile electric, barbed wire, slanted, poly mesh, and electrified poly tape and poly rope. Variables to be considered when selecting an appropriate fence design include value of the resources to be protected, level of protection desired, seasonality of the resource being protected, physical ability of the target species, motivation to breach, behavioural characteristics, costs associated with constructing and maintaining the fence, longevity of the fence and possible negative effects of erecting a fence (VerCauteren et al. 2006c). Although fences may have potential to eliminate damage, their expense may make them costprohibitive, especially in situations where the value of the resources being protected is low and the area to be protected is large (VerCauteren et al. 2006c). In addition to size, shape and perimeter of the area influence the amount and cost of fencing required (Conover 2002).

Basic designs are used routinely to exclude (Byrne 1989), contain (Bryant et al. 1993) and direct elk movements (Smith 
2001). The United States Forest Service-owned Starkey Experimental Forest and Range in Oregon contains several hundred elk and deer individuals within a $101-\mathrm{km}^{2}$ enclosure surrounded by a 2.4-m-tall woven-wire mesh fence topped by two strands of high-tensile smooth wire (Bryant et al. 1993). Nearly $70 \mathrm{~km}$ of fence make up the enclosure and cross-fences that are expected to last at least 30 years. At least two male elk individuals were observed breaching the fence between the mesh and smooth wire and others have breached by unknown means (Bryant et al. 1993). The captive cervid industry routinely uses similar fences to confine elk and other big game species for management and husbandry. In addition, extensive game fences are used across much of southern Africa to control movements and possession of large herbivores, such as kudu, oryx, wildebeest and zebra (Whyte and Joubert 1988).

Wildlife managers have used fences to exclude elk from concentrated resources (e.g. stored crops) and areas of dispersed resources (e.g. crop fields, orchards; Schneidmiller 1987; Byrne 1989; Smith 2001). Out of economic necessity, non-traditional fences have received more attention in development and evaluation. Byrne (1989) and Schneidmiller (1987) reviewed a variety of novel techniques for excluding cervids from stored livestock feed. Schneidmiller (1987) stated that a 1.8-2.1-m fence constructed of 50\% woven-wire mesh and $50 \%$ multiple strands of barbed wire spaced at $15-\mathrm{cm}$ intervals provided the best long-term protection. Goddard et al. (2001) tested a variety of fences for red deer and found a 1.9-m wovenwire mesh fence was entirely effective in restricting movements whereas a fence constructed of 0.8-m woven-wire mesh topped by four strands of 1.1-m webbing allowed passage by a small percentage of test animals. A 0.76-m, two-wire fence did not deter crossings by pronghorn (Antilocapra americana), elk and mule deer, whereas a 1.32-m, four-wire fence deterred crossings by $>40 \%$ of approaching elk individuals (Karhu and Anderson 2006).

Herbivore exclosures often are an important component of research on rangeland vegetation (e.g. Gross and Knight 2000) and an effective means for eliminating small-scale damage (Nolte 1999). A criticism of common exclosures has been that most of the effects of mammalian herbivory are eliminated and this is not comparable to natural conditions, thus providing an invalid comparison of effects of browsing by herbivores (Gross and Knight 2000). VerCauteren et al. (2007b) designed and evaluated a fence intended to exclude elk while allowing passage by other wildlife species, and thus providing a more accurate comparison for herbivory research; the design is currently being used and evaluated (Gage and Cooper 2009).

Exclosures and boundary fences within national parks have been used for decades to alleviate and evaluate herbivore damage (e.g. Bauman et al. 1999; Schoenecker et al. 2004). Proposals for large-scale fencing installations to provide protection to vegetation for 30-50 years from elk in ROMO were favoured by only $30 \%$ of survey respondents, suggesting that not all visitors were in favour of this method of protection for sensitive areas (Stewart et al. 2004). A 1.52-1.84-m woven-wire mesh fence (1.22-1.54-m woven-wire mesh plus two strands of barbed wire 0.15 and $0.30 \mathrm{~m}$ above the woven wire) installed along the boundary of Wind Cave National Park, South Dakota, USA, allowed regular passage by elk and deer; however, the fence was frequently compressed to $0.91-1.22 \mathrm{~m}$ by jumping animals (Bauman et al. 1999). Movements by elk across fences increased during spring and fall, likely because of rut, hunting, seasonal migration or calving (Bauman et al. 1999). Increased movements across fences suggested that elk's motivation to breach and potential for damage are likely to be highest during periods influenced by behaviour (e.g. breeding) and anthropogenic disturbance (e.g. hunting). When compared with mule deer, elk spent considerably more time milling about and investigating a fence before jumping (Bauman et al. 1999). Elk damage to livestock fences is an issue of contention because of the potential for livestock escapes and labour and costs associated with repairs (Harrington and Conover 2006). Although elk frequently compress and break fences at common crossing points, many options (e.g. ramps, gap between wires) are available for creating points where passage is easier and damage less likely (Witham 1996; Knight et al. 1997).

Buck-and-pole fences (1.83 $\mathrm{m}$ in height) along the northern boundary of Yellowstone National Park, Montana, USA, appeared to be a substantial barrier to animals that rely on jumping to breach such fences (Scott 1992). Buck-and-pole fences provide a seemingly effective barrier with an aesthetically pleasing appearance, offering an option for applications where public perception is a concern. Although elk were less likely to cross buck-and-pole fences than were deer and pronghorn, damaged fences could allow elk to cross if not properly maintained.

Extensive fences have been installed to minimise cervid-vehicle collisions in some locales by excluding animals from roads (Bashore et al. 1985; Feldhamer et al. 1986; Clevenger et al. 2001) or funneling animals to common crossing points associated with structures designed to enable safe passage (e.g. crosswalks, bridges or underpasses; e.g. Ward 1982; Lehnert and Bissonette 1997; D'Angelo et al. 2007; Bissonette and Cramer 2008). D'Angelo et al. (2007) conducted a comprehensive review of techniques available to reduce deer-vehicle collisions by excluding deer from roadways.

The weakest links in fences are gates, which must be closed to make fences effective. Automatically closing gates, electrified mats and active as well as passive cattle-guard devices have been evaluated with mixed results (Peterson et al. 2003; Seamans and Helon 2008; VerCauteren et al. 2009). Electrified mats were effective in excluding elk from stands of red willow and portions of roadways outside of developed animal 'crosswalks' in Arizona (R. Lampman, ElectroBraid Fence Ltd, pers. comm.).

A variety of devices are available that provide protection to individual plants or parts of plants in situations where fences are impractical or only temporary protection is needed (e.g. Campbell et al. 1988). Protection is provided by limiting access to roots, stems, foliage and growing points until plants are less vulnerable to serious damage. Chicken-wire cylinders, photodegradable polypropylene cylinders (i.e. Tubex ${ }^{\mathrm{TM}}$; Treessential Company, Saint Paul, MN) and a variety of flexible mesh sleeves (i.e. Vexar ${ }^{\circledR}$; DuPont Canada, Whitby, Ontario) can effectively protect seedlings (i.e. Fagerstone and Clay 1997; Taylor et al. 2006). Protective cylinders provide exclusion only until the terminal bud protrudes from the top of the cylinder, and then it is advantageous to apply bud caps. One benefit of protecting individual plant parts is that animals are not completely excluded 
from portions of their habitat. The number of plants (usually tree seedlings) and the size of the area being protected must be considered, because the cost of protecting individual plants may approach the expense of fencing the entire area (Campbell et al. 1988; Taylor et al. 2006).

Fences can be used to exclude elk from an area (i.e. wire-mesh) or protect individual regenerating tree species (i.e. Tubex) from browse damage. Cost, efficacy, duration of protection needed, maintenance and permeability to non-target wildlife should be considered before use of fences to exclude elk.

\section{Habitat modification}

Reduction of permanent cover in a localised area could reduce the use of an area by the population for a particular landscape, and would also destroy habitat that is important for other wildlife (Craven and Hygnstrom 1994). Removal and extensive maintenance of vegetation adjacent to roadways are often conducted to reduce potential for animal collisions with vehicles. Selection of plants for landscaping, on the basis of palatability or resistance to cervid damage, can minimise the use and damage to plantings by cervids (Craven and Hygnstrom 1994). Fargione et al. (1991) presented a list of common plants and their susceptibility to damage by deer in North America. Hay bales should be brought in from fields and crops should be harvested as early as possible to minimise the duration of time they are susceptible to damage.

Lure crops (Nolte 1999; Smith 2001) or strategic provisioning of desirable foods (Doenier et al. 1997) have been used to divert cervids from more valuable crops. However, providing additional forage leads to higher reproductive and survival rates, and congregates animals (Hines et al. 2007), which may lead to additional crop damage (e.g. Long 1989) and potential for transmission of disease between wildlife and livestock (Miller et al. 2003; Dean et al. 2004).

Improvement of habitat or forage conditions adjacent to areas where damage is occurring (e.g. croplands, orchards) has potential to alleviate damage situations. Herbicide application, followed by fertiliser (Ramsey and Krueger 1986; Witmer and Cogan 1989) or seeding and fertilising food plots (Bayoumi and Smith 1976; Skovlin et al. 1983; Ramsey and Krueger 1986), was used successfully to mitigate crop damage in several instances. Basic application of fertiliser to rangeland was suggested to alleviate damage on adjacent cropland by improving nutritional quality and quantity of forage (Craven and Hygnstrom 1994), resulting in increased use by elk. Cost and effectiveness of methods to divert animal use has not been investigated and requires further investigation.

Use of mineral supplements (e.g. salt blocks) was a common management technique for manipulating range use by wild cervids during the first half of the last century (Case 1938; Stockstad et al. 1953; Williams 1962; Dalke et al. 1965). Wildlife managers created artificial salt licks by strategically placing $23-136 \mathrm{~kg}$ of crude rock salt to reduce numbers of animals using natural licks, disperse use of available forage, prevent crop damage and increase hunter harvest (Case 1938; Cooney 1952; Stockstad et al. 1953; Dalke et al. 1965). Most forage does not contain an adequate amount of sodium for lactation or antlerogenesis; thus, sodium-containing compounds are commonly sought by cervids (Short et al. 1966; Belovsky and Jordan 1981; Holdø et al. 2002; Ayotte et al. 2006) from both natural and anthropogenic sources. Use of mineral supplements is likely to be effective seasonally (e.g. females during lactation in spring); however, visitation would not be often enough to redistribute elk and would concentrate elk to a common source, potentially increasing disease transmission.

Habitat modification to redistribute elk to alternate sites requires thorough knowledge of movements and forage requirements of offending animals to be successful. Furthermore, shifting range use and altering movements of elk at the landscape-scale are unlikely because most studies were able to alter or observe the range use only seasonally or during specific life stages (i.e. summer lactation or antlerogenesis; Knight and Mudge 1967; Nolte 1999; Holdø et al. 2002).

\section{Frightening}

Frightening options rely on conditioning of target animals by delivering a stimulus (e.g. loud sound, scary image) to induce a sensation (e.g. anxiety, fear, pain), followed by a desired response (e.g. dispersal, flight) in target animals. Non-lethal frightening devices often mimic characteristics of predators (e.g. smell, sound, appearance) to target specific senses. Unfortunately, when techniques are not supported by negative physical stimuli (e.g. shock, physical contact), fear of inanimate or active objects often wanes and habituation often follows (Nolte 1999). More effective techniques provide increased protection by targeting several senses (Nolte 1999). Seward et al. (2007) and Nolte et al. (2003) developed and evaluated techniques for alleviating deer damage through delivery of negative stimuli. Further, providing negative physical stimuli appears to improve efficacy, although this has not been widely evaluated in elk, except when combined with fences to physically exclude target animals (e.g. electrified and barbed-wire fence; McKillop and Sibly 1988; J. W. Fischer, USDA/APHIS/WS National Wildlife Research Center, unpubl. data).

Several frightening devices have been designed for use by farmers, homeowners and professionals to alleviate damage caused by wildlife. Frightening techniques typically incorporate the following modes of action: audio-visual and biological. Initially, animals often respond to novel objects, used as frightening devices, in their surroundings, providing users with a sense of success. However, frightening devices are generally not effective for extended periods (Bomford and O'Brien 1990; Koehler et al. 1990; Gilsdorf et al. 2002, 2004b), although they may be useful for a user to alleviate damage long enough, such as while migrating elk individuals pass through an area (Nolte 1999).

Most research on frightening devices for cervids has focused on white-tailed deer (e.g. Belant et al. 1996, 1998; Beringer et al. 2003); limited research results have been published regarding efficacy of frightening devices for elk and mule deer (VerCauteren et al. 2005b). Elk seem to habituate rapidly to sound-emitting frightening devices, rendering them ineffective in alleviating damage (Henigman et al. 2005).

Propane cannons, shell crackers and other sonic devices used near at-risk resources can provide temporary relief from cervid 
damage (Gilsdorf et al. 2002); however, these and similar frightening tools are generally ineffective, even for short periods (Koehler et al. 1990; Belant et al. 1998; Gilsdorf et al. 2004a). Efficacy may be improved by simultaneously incorporating a variety of stimuli (Nolte 1999; Shivik and Martin 2000; Gilsdorf et al. 2002; Beringer et al. 2003), frequent movement (Koehler et al. 1990) and activation by offending animals (Belant et al. 1996; Beringer et al. 2003). Devices that are activated regardless of the presence of animals or those that trigger at regular intervals are less effective than those that activate only in the presence of offending animals (Gilsdorf et al. 2004b). Active infrared beams (a beam sent from a transmitter to a receiver that triggers the device when broken) or passive infrared sensors (detect movement of an object of different heat from surroundings) often are incorporated to enable activation.

Although research on elk is not available, acute vision of deer often supports other senses, working synergistically with smell or hearing (Muller-Schwarze 1994; VerCauteren and Pipas 2003), and has been the basis for strategies attempted to deter deer from sensitive resources (VerCauteren and Pipas 2003). Red lasers were effective in dispersing some bird species (Blackwell et al. 2002), whereas they were ineffective in dissuading deer use of resources because deer are not likely to perceive colours in the range of $630-650 \mathrm{~nm}$ (i.e. red; VerCauteren and Pipas 2003; VerCauteren et al. 2003). Even when confronted at night with laser lights in their range of vision $(450-537 \mathrm{~nm}$; bluegreen), a flight response was not elicited by deer (VerCauteren et al. 2006a). Further, VerCauteren et al. (2005b) evaluated a commercially marketed frightening device that incorporated both visual (red light) and auditory stimuli and demonstrated that neither stimulus was sufficient to cease damage by deer or elk.

Although some multi-stimulus devices have proven ineffective (Roper and Hill 1985; Koehler et al. 1990; Belant et al. 1998), Beringer et al. (2003) developed and evaluated a device with acoustic and visual stimuli that repelled white-tailed deer from soybean plots for 6 weeks, which was also the extent of the study. Beringer et al. (2003) selected sounds likely to frighten deer (i.e. aggressive dogs, gunshot barrages, cervid distress calls), incorporated deer activation and included a rapidly moving illuminated human effigy. Suggesting the importance of integrating multiple stimuli, a similar device that was strictly acoustic was insufficient at protecting corn from deer during silking-tasseling stages (Gilsdorf et al. 2004b). Nolte (1999) suggested that supplementing pyrotechnic use (i.e. auditory cue) with an occasional impact by a rubber bullet (i.e. physical cue) might provide sufficient negative stimuli and improve dispersal of elk. Seward et al. (2007) developed a frightening device that included a physical stimulus (i.e. slapped by a polyvinyl chloride conduit arm) and effectively deterred deer from using cattle feed.

The most effective frightening devices developed target multiple senses, including touch. The focus of future research on frightening devices for deterring cervids from sensitive resources should take this into consideration (Gilsdorf et al. 2002, 2004b). Although most research has been conducted on deer, the use of frightening devices on elk are likely to be effective only in short durations, require multiple stimuli (i.e. auditory and physical cues) and regular maintenance, and be animal activated.

\section{Hazing}

Hazing requires a continued disturbance and disruption of behavioural patterns of problem animals by the persistent use of a variety of frightening techniques, including pyrotechnics, dogs and humans on foot, horseback, or in vehicles. Humaninduced disturbance or continual harassment of elk in sensitive areas has recently received increased attention from researchers and wildlife managers. Recreational activities, hunting, roads and vehicular travel have all influenced elk activity (Schultz and Bailey 1978; Rowland et al. 2000; Trombulak and Frissell 2000; Conner et al. 2001; Vieira et al. 2003). Yet it is still a challenge to disperse elk in certain areas such as National and Provincial Parks (Schultz and Bailey 1978; Thompson and Henderson 1998; Bauman et al. 1999). Elk in Yellowstone National Park, where lethal methods of managing the population were abandoned in 1969, have demonstrated sensitivity to human activity and flee when cross-country skiers approach within $650 \mathrm{~m}$ (Cassirer et al. 1992). Conversely, Schultz and Bailey (1978) found that elk individuals in ROMO were reluctant to flee when approached by humans on foot (mean distance approached to induce flight $=85.8 \mathrm{~m}$ ) and often required three or four approaches before they would retreat to escape cover. Lethal methods of population control in ROMO ceased in 1962, followed by a noted decrease in sensitivity to human activity by elk (D. Stevens, ROMO biologist; pers. comm. in Schultz and Bailey 1978). Researchers observed an influx of elk coincident with opening of hunting season on public lands adjacent to ROMO (Schultz and Bailey 1978), demonstrating that elk use ROMO as refugia. In north-western Colorado, where hunting occurred, elk vacated public lands on the opening of archery season and moved to adjacent private lands where less hunting activity occurred (Conner et al. 2001; Vieira et al. 2003). Select activities, such as those simulating hunting, at strategically scheduled times on established refugia may enable land and wildlife managers to counteract the effects of opening of hunting seasons (i.e. movement to refugia), thereby bolstering hunter success and enabling managers to achieve population goals more effectively.

Hazing procedures induce an escape response in wildlife to avoid potential negative consequences (i.e. perceived predation) by approaching humans or dogs (Kloppers et al.2005). Reduction of habituation through hazing has not been evaluated in elk or deer to a great extent (Frid and Dill 2002; Kloppers et al. 2005). Where hunting occurs, human disturbance might be perceived by elk in some settings as a predation threat similar to that posed by wolves (Kilpatrick et al. 2009; Plumb et al. 2009), demonstrating a vulnerability of elk that may enable hazing to be an effective tool for stimulating dispersal. Managers routinely haze bison (Kilpatrick et al. 2009; Plumb et al. 2009) and elk away from sensitive areas (Neff 2007; Washington Department of Fish and Wildlife 2009). Hazing, herding (defined as an active pursuit of elk to a distant destination) and hunting occurred during a study in Montana, and although data were not reported, researchers found hunting was the only effective method in dispersing elk off refugia on private land (Burcham et al. 1999). Hazing of elk with dogs in 
ROMO to alleviate habitat damage was more acceptable to visitors (45\% of Colorado survey respondents) than was hazing with rubber bullets $(30 \%)$ or noise $(20 \%$; Stewart et al. 2004). Hazing or targeted disturbances reduced reproductive success of elk in Colorado and could be implemented to reduce population growth in some areas (Phillips and Alldregde 2000; Shively et al. 2005). Furthermore, strategically scheduled hazing during various times of year (e.g. during calving in spring, or hunting seasons in autumn) may be effective in inducing dispersals and even population reductions by redistributing elk individuals to areas where they are vulnerable to harvest by hunters.

Livestock protection dogs (LPDs) have been used for $>2000$ years to control predation on livestock in Europe (Coppinger et al. 1987; Green and Woodruff 1990; Gehring et al. 2010). Previous studies reported that LPDs occasionally chased deer (VerCauteren et al. 2008) and reindeer (Rangifer tarandus; Hansen and Bakken 1999). Interest in chasing deer, combined with their affinity to livestock, makes LPDs useful for keeping deer from contacting cattle and cattle feed, thereby reducing potential for deer to transmit $M$. bovis to cattle (VerCauteren et al. 2008) and brucellosis between elk and cattle in the western USA (Bienen and Tabor 2006). LPDs reduced deer use of cattle pastures, excluded deer from cattle feed and minimised interactions between deer and cattle (Woodruff and Green 1995). Dogs have also been used to protect diverse resources such as forest plantations (Beringer et al. 1994), golf courses (Castelli and Sleggs 2000), office complexes (Curtis and Rieckenberg 2005), orchards (VerCauteren et al. 2005a; R. P. Coppinger, Hampshire College, unpubl. report) and vegetable farms (Rigg 2001; Curtis and Rieckenberg 2005) from a variety of wildlife. Dogs within the perimeter of invisible fencing systems that surround agricultural crops reduced damage by deer (Curtis and Rieckenberg 2005; VerCauteren et al. 2005a) and several producers used dogs to protect orchards and annual crops (Beringer et al. 1994). Selection, training and care of dogs are important components of the success of this strategy. Use of dogs in a passive manner to reside in and protect an area, such as a stand of sensitive vegetation, has potential for success if thoughtful selection of breed and introduction of the dog are performed. Dogs should be of breeds that are territorial and demonstrate a patrolling behaviour for effective protection of space and inanimate objects such as crop fields (VerCauteren et al. 2005a). Working breeds such as Siberian husky and Alaskan malamute have performed well in protecting specific areas (VerCauteren et al. 2005a), are hardy dogs that are well adapted to harsh winter conditions and have a wolf-like appearance which may result in their being perceived by elk as threatening predators.

Incorporation of dogs into hazing regimes for cervids should focus on several behaviours possessed by specific breeds. Great Pyrenees readily pursued deer but needed encouragement from handlers (VerCauteren et al. 2008). Alaskan malamutes and Siberian huskies used to protect crops naturally pursued deer without encouragement (VerCauteren et al. 2005a). Kloppers et al. (2005) used border collies near Banff National Park, Alberta, Canada, to disperse habituated elk individuals that were a nuisance in the town of Banff. The border collies acted in a silent and controlled manner when directed by handlers to herd elk individuals in a desired direction. It is likely that other breeds would influence reactions of elk differently. Kloppers et al. (2005) found that hazing with dogs was effective for dispersing elk and no signs of habituation to hazing were observed. Hazing with dogs did not provide additional motivation, however, beyond the level provided by humans alone. In addition, the effects of true predation by adjacent packs of wolves counteracted the desired effects achieved by hazing with dogs because elk would return to the area of conflict in response to harassment by wolf packs in areas to which elk were hazed (i.e. Banff National Park; Kloppers et al. 2005).

Hazing of elk has received considerable attention recently and appears to be focused on reversing habituation in humandominated landscapes or mimicking predators to redistribute elk individuals away from sensitive habitats (i.e. regenerating aspen stands). Hazing of elk can target a specific habitat in need of protection from elk, focus on particular elk causing conflicts with humans, and be implemented in various habitats of differing configurations.

\section{Summary and research needs}

Elk management is a complex process of understanding distribution and ecology of populations of elk, along with land-ownership and public desire for particular management strategies. Specific lethal (e.g. hunting, sharpshooting) options for managing free-ranging populations of elk are not publicly acceptable in many urban and suburban communities because of perceived safety concerns, and non-lethal (e.g. contraception, relocation) options are often not practical or economically feasible. Frightening techniques are effective only for short durations, require regular maintenance to work properly and habituation by elk is likely; consequently, their long-term use is not recommended. Although fencing can be effective in many situations, installation of fences around large tracts of regenerating vegetation is often cost-prohibitive and aesthetically unappealing to landowners or visitors to parks and preserves. Recently, herding and hazing of elk by humans with dogs or on horseback has been successful at preventing the use of urban and sensitive areas by elk near Banff National Park, Alberta, Canada (Kloppers et al. 2005). The use of avoidance conditioning with dogs to mimic disturbance by predators appears to be a publicly acceptable method and is currently being explored for dispersing habituated elk individuals (Stewart et al. 2004). Hazing of elk with rubber bullets or loud noises was considered less acceptable by park visitors and nearby residents of ROMO and Banff National Park (Stewart et al. 2004; Kloppers et al. 2005); however, it may be feasible on private landholdings.

Considerable funding has been allocated for research and management of lethal methods, fertility control, repellents, frightening devices and fencing. Although several methods are available to control human-elk conflicts, variation in land uses and societal values means that solutions may have to be sitespecific. Public perception and involvement in elk-human conflicts has resulted in several non-lethal methods being employed (i.e. fertility control, lasers, pyrotechnics); however, additional research should be conducted to determine their effectiveness on elk. Furthermore, several non-lethal methods 
are effective only for short durations and elk may habituate to some options, suggesting that resource managers may need to employ full-time staff to address elk-human conflicts. Hazing crews with dogs, on horseback, or with rubber bullets/shot, or even paintballs, may need to be a consistent threat to elk throughout the year to be effective and to prevent elk-human conflicts in some areas. Although aversive conditioning has been effective at dispersing elk from urban areas in the short term, longterm effectiveness remains unclear, and merits further research.

\section{Acknowledgements}

Support for this research was provided by the National Park Service, USDA-APHIS-WS-National Wildlife Research Center, and the University of Nebraska-Lincoln. Special thanks go to H. Van Roekel and M. Howell for obtaining the literature and G. Clements and A. Hildreth for compiling and organising the database of literature used during the preparation of this manuscript.

\section{References}

American Veterinary Medical Association (AVMA) (2007). 'AVMA Guidelines on Euthanasia.' Available at http://www.avma.org/issues/ animal_welfare/euthanasia.pdf [accessed 15 June 2010].

Andelt, W. F., Burnham, K. P., and Manning, J. A. (1991). Relative effectiveness of repellents for reducing mule deer damage. The Journal of Wildlife Management 55, 341-347. doi:10.2307/3809161

Andelt, W. F., Baker, D. L., and Burnham, K. P. (1992). Relative preference of captive cow elk for repellent-treated diets. The Journal of Wildlife Management 56, 164-173. doi:10.2307/3808805

Andelt, W. F., Burnham, K. P., and Baker, D. L. (1994). Effectiveness of capsaicin and bitrex repellents for deterring browsing by mule deer. The Journal of Wildlife Management 58, 330-335. doi:10.2307/3809398

Angradi, T. R., and Tzilkowski, W. M. (1987). Preliminary testing of a selenium-based systemic deer browse repellent. Proceedings of the Eastern Wildlife Damage Control Conference 3, 102-107.

Ayotte, J. B., Parker, K. L., Arocena, J. M., and Gillingham, M. P. (2006). Chemical composition of lick soils: functions of soil ingestion by four ungulate species. Journal of Mammalogy 87, 878-888. doi:10.1644/06MAMM-A-055R1.1

Baker, D. L., and Hobbs, N. T. (1982). Composition and quality of elk summer diets in Colorado. The Journal of Wildlife Management 46, 694-703. doi:10.2307/3808561

Baker, D. L., Andelt, W. F., Burnham, K. P., and Shepperd, W. D. (1999). Effectiveness of Hot Sauce ${ }^{\circledR}$ and Deer Away ${ }^{\circledR}$ repellents for deterring elk browsing of aspen sprouts. The Journal of Wildife Management 63, 1327-1336. doi:10.2307/3802851

Baker, D. L., Wild, M. A., Hussain, M. D., Dunn, R. L., and Nett, T. M. (2005). Evaluation of remotely delivered leuprolide acetate as a contraceptive agent in female elk (Cervus elaphus nelsoni). Journal of Wildlife Diseases 41, 758-767.

Bashore, T. L., Tzilkowski, W. M., and Bellis, E. D. (1985). Analysis of deer-vehicle collision sites in Pennsylvania. The Journal of Wildlife Management 49, 769-774. doi:10.2307/3801709

Bauman, P. J., Jenks, J. A., and Roddy, D. E. (1999). Evaluating techniques to monitor elk movement across fence lines. Wildlife Society Bulletin 27, 344-352.

Bayoumi, M. A., and Smith, A. D. (1976). Response of big game winter range vegetation to fertilization. Journal of Range Management 29, 44-48. doi: $10.2307 / 3897689$

Beck, J. L., and Peek, J. M. (2005). Diet composition, forage selection and potential for forage competition among elk, deer and livestock on aspen-sagebrush summer range. Rangeland Ecology and Management 58, 135-147. doi:10.2111/03-13.1
Belant, J. L., Seamans, T. W., and Dwyer, C. P. (1996). Evaluation of propane exploders as white-tailed deer deterrents. Crop Protection 15, 575-578. doi:10.1016/0261-2194(96)00027-0

Belant, J. L., Seamans, T. W., and Tyson, L. A. (1998). Evaluation of electronic frightening devices as white-tailed deer deterrents. Proceedings of the Vertebrate Pest Conference 18, 107-110.

Belovsky, G. E., and Jordan, P. A. (1981). Sodium dynamics and adaptations of a moose population. Journal of Mammalogy 62, 613-621. doi:10.2307/ 1380408

Beringer, J., Hansen, L. P., Heinen, R. A., and Geissman, N. F. (1994). Use of dogs to reduce damage by deer to a white pine plantation. Wildlife Society Bulletin 22, 627-632.

Beringer, J., Hansen, L. P., Wilding, W., Fischer, J., and Sheriff, S. L. (1996). Factors affecting capture myopathy in white-tailed deer. The Journal of Wildlife Management 60, 373-380. doi:10.2307/3802238

Beringer, J., Hansen, L. P., Demand, J. A., Sartwell, J., Wallendorf, M., and Mange, R. (2002). Efficacy of translocation to control urban deer in Missouri: costs, efficiency, and outcome. Wildlife Society Bulletin 30, 767-774.

Beringer, J., VerCauteren, K. C., and Millspaugh, J. J. (2003). Evaluation of an animal activated scarecrow and a monofilament fence for reducing deer use of soybean fields. Wildlife Society Bulletin 31, 492-498.

Beschta, R. L., and Ripple, W. J. (2006). River channel dynamics following extirpation of wolves in northwestern Yellowstone National Park, USA. Earth Surface Processes and Landforms 31, 1525-1539. doi:10.1002/ esp. 1362

Bienen, L., and Tabor, G. (2006). Applying an ecosystem approach to brucellosis control: can an old conflict between wildlife and agriculture be successfully managed? Frontiers in Ecology and the Environment 4, 319-327. doi:10.1890/1540-9295(2006)4[319:AAEATB]2.0.CO;2

Biggs, J., Sherwood, S., Michalak, S., Hansen, L., and Bare, C. (2004). Animal-related vehicle accidents at the Los Alamos Nationa Laboratory, New Mexico. The Southwestern Naturalist 49, 384-394. doi:10.1894/ 0038-4909(2004)049<0384:AVAATL >2.0.CO;2

Bissonette, J. A., and Cramer, P. C. (2008). Evaluation of the use and effectiveness of wildlife crossings. National Cooperative Highway Research Program Report 615. Transportation Research Board, Washington, DC.

Blackwell, B. F., Bernhardt, G. E., and Dolbeer, R. A. (2002). Lasers as nonlethal avian repellents. The Journal of Wildlife Management 66, 250-258. doi: $10.2307 / 3802891$

Bomford, M., and O'Brien, P. H. (1990). Sonic deterrents in animal damage control: a review of device tests and effectiveness. Wildlife Society Bulletin 18, 411-422.

Boyce, M. S. (1989). 'The Jackson Elk Herd: Intensive Wildlife Management in North America.' (Cambridge University Press: New York.)

Bradford, J., and Hobbs, N. T. (2006). Analysis of options for elk population management in Rocky Mountain National Park - results of additional scenarios. Report to the National Park Service. Rocky Mountain National Park, Estes Park, CO.

Bradford, J. B., and Hobbs, N. T. (2008). Regulating overabundant ungulate populations: an example for elk in Rocky Mountain National Park, Colorado. Journal of Environmental Management 86, 520-528. doi:10.1016/j.jenvman.2006.12.005

Brelsford, M. J., Peek, J. M., and Murray, G. A. (1998). Effects of grazing by wapiti on winter wheat in northern Idaho. Wildlife Society Bulletin 26, 203-208.

Brook, R. K., and McLachlan, S. M. (2006). Factors influencing farmers' concerns regarding bovine tuberculosis in wildlife and livestock around Riding Mountain National Park. Journal of Environmental Management 80, 156-166. doi:10.1016/j.jenvman.2005.08.022

Brookshire, J., Kauffman, J. B., Lytjen, D., and Otting, N. (2002). Cumulative effects of wild ungulate and livestock herbivory on riparian willows. Oecologia 132, 559-566. doi:10.1007/s00442-002-1007-4 
Bryant, B. K., and Ishmael, W. E. (1991). Movement and mortality patterns of resident and translocated suburban white-tailed deer. In 'Proceedings of the National Institute for Urban Wildlife Symposium'. (Eds L. W. Adams and D. L. Leedy.) pp. 53-58. (National Institute for Urban Wildlife: Columbia, MD.)

Bryant, L. D., Thomas, J. W., and Rowland, M. M. (1993). Techniques to construct New Zealand elk-proof fence. United States Department of Agriculture, General Technical Report PNW-GTR-313. United States Forest Service, Pacific Northwest Research Station, Portland, OR.

Bunnell, S. D., Wolfe, M. L., Brunson, M. W., and Potter, D. R. (2002). Recreational use of elk. In 'North American Elk: Ecology and Management'. (Eds D. E. Toweill and J. W. Thomas.) pp. 701-747. (Smithsonian Institute Press: Washington, DC.)

Burcham, M., Edge, W. D., and Marcum, C. L. (1999). Elk use of private land refuges. Wildlife Society Bulletin 27, 833-839.

Byrne, E. A. (1989). Experimental applications of high-tensile wire and other fencing to control big game damage in northwest Colorado. Proceedings of the Great Plains Wildlife Damage Control Workshop 9, 109-115.

Campbell, D. L., Evans, J., and Hartman, G. B. (1988). Evaluation of seedling protection materials in western Oregon. Technical note OR-5. United States Department of the Interior, Bureau of Land Management, Portland, OR.

Case, G. W. (1938). The use of salt in controlling the distribution of game. The Journal of Wildlife Management 2, 79-81. doi:10.2307/3796428

Case, R. L., and Kauffman, J. B. (1997). Wild ungulate influences on the recovery of willows, black cottonwood and thin-leaf alder following cessation of cattle grazing in northeastern Oregon. Northwest Science 71, 115-126.

Cassirer, E. F., Freddy, D. J., and Ables, E. D. (1992). Elk reponses to disturbance by cross-country skiers in Yellowstone National Park. Wildlife Society Bulletin 20, 375-381.

Castelli, P. M., and Sleggs, S. E. (2000). Efficacy of border collies to control nuisance Canada geese. Wildlife Society Bulletin 28, 385-392.

Chase, L. C., and Decker, D. J. (1998). Citizen attitude toward elk and participation in elk management: a case study in Evergreen, Colorado. Human Dimensions of Wildlife 3, 55-56.

Clarke, J. A., Olmsted, C. E., and Larkins, K. (1994). Patterns of habitat use, movement, and distribution of elk adjacent to the eastern boundary of Rocky Mountain National Park. Summary report, solicitation \#1443RP1520920002. University of Northern Colorado, Greeley, CO.

Clevenger, A. P., Chruszcz, B., and Gunson, K. E. (2001). Highway mitigation fencing reduces wildife-vehicle collisions. Wildlife Society Bulletin 29, 646-653.

Conner, M. M., White, G. C., and Freddy, D. J. (2001). Elk movement in response to early-season hunting in northwest Colorado. The Journal of Wildlife Management 65, 926-940. doi:10.2307/3803041

Conner, M. M., Baker, D. L., Wild, M. A., Powers, J. G., Hussain, M. D., Dunn, R. L., and Nett, T. M. (2007). Fertility control in free-ranging elk using gonadotropin-releasing hormone agonist leuprolide: effects on reproduction, behavior and body condidion. The Journal of Wildlife Management 71, 2346-2356. doi:10.2193/2006-463

Conover, M. R. (1984). Effectiveness of repellents in reducing deer damage in nurseries. Wildlife Society Bulletin 12, 399-404.

Conover, M. (2002). 'Resolving Human-wildlife Conflicts: The Science of Wildlife Damage Management.' (Lewis Publishers: Boca Raton, FL.)

Cooney, R. F. (1952). Elk problems in Montana. Journal of Range Management 5, 3-7. doi: $10.2307 / 3893978$

Cooper, A. B., Stewart, F., Unsworth, J. W., Kuck, L., McArthur, T. J., and Rachael, J. S. (2002). Incorporating economic impacts into wildlife management decisions. Wildlife Society Bulletin 30, 565-574.

Coppinger, R., Lorenz, J., and Coppinger, L. (1987). New uses of livestock guarding dogs to reduce agriculture/wildlife conflicts. Proceedings of the Eastern Wildlife Damage Control Conference 3, 253-259.
Coughenour, M. B., and Singer, F. J. (1996). Elk population processes in Yellowstone National Park under the policy of natural regulation. Ecological Applications 6, 573-593. doi:10.2307/2269393

Craven, S. R., and Hygnstrom, S. E. (1994). Deer. In 'Prevention and Control of Wildlife Damage'. (Eds S. Hygnstrom, R. Timm and G. Larsen.) pp. D-25-D-40. (University of Nebraska Press: Lincoln, NE.)

Creel, S., Winnie, J. Jr, Maxwell, B., Hamlin, K., and Creel, M. (2005). Elk alter habitat selection as an antipredator response to wolves. Ecology 86, 3387-3397. doi:10.1890/05-0032

Cromwell, J. A., Warren, R. J., and Henderson, D. W. (1999). Live-capture and small-scale relocation of urban deer on Hilton Head Island, South Carolina. Wildlife Society Bulletin 27, 1025-1031.

Cross, P. C., Edwards, W. H., Scurlock, B. M., Maichak, E. J., and Rogerson, J. D. (2007). Effects of management and climate on elk brucellosis in the greater Yellowstone ecosystem. Ecological Applications 17, 957-964. doi:10.1890/06-1603

Cross, P. C., Heisey, D. M., Scurlock, B. M., Edwards, W. H., Ebinger, M. R., and Brennan, A. (2010). Mapping brucellosis increases relative to elk density using hierarchical Bayesian models. PLOS ONE 5, e10322. doi:10.1371/journal.pone. 0010322

Curtis, P. D., and Rieckenberg, R. (2005). Use of confined dogs for reducing deer damage to apple orchards. Proceedings of the Wildlife Damage Management Conference 11, 149-158.

D’Angelo, G. J., Warren, R. J., Miller, K. V., Gallagher, G. R., and Valitzski, S. A. (2007). Development and evaluation of devices designed to minimize deer-vehicle collisions. Final Project Report, Georgia Department of Transportation. University of Georgia, Athens, GA.

Dalke, P. D., Beeman, R. D., Kindel, F. J., Robel, R. J., and Williams, T. R. (1965). Use of salt by elk in Idaho. The Journal of Wildlife Management 29, 319-332. doi:10.2307/3798437

Daniels, M. J., Hutchings, M. R., and Greig, A. (2003). The risk of disease transmission to livestock posed by contamination of farm stored feed by wildlife excreta. Epidemiology and Infection 130, 561-568.

Dean, R., Gocke, M., Holz, B., Kilpatrick, S., Kreeger, T. J., Scurlock, B., Smith, S., Thorne, E. T., and Werbelow, S. (2004). 'Elk Feedgrounds in Wyoming.' (Wyoming Department of Game and Fish: Jackson, WY.)

Deblinger, R. D., Rimmer, D. W., Vaske, J. J., Vecellio, G. M., and Donnelly, M. P. (1993). Ecological benefits and hunter acceptance of a controlled deer hunt in coastal Massachusetts. Northeast Wildlife 50, 11-21.

DeNicola, A. J., and Williams, S. C. (2008). Sharpshooting suburban whitetailed deer reduces deer-vehicle collisions. Human-Wildlife Conflicts $\mathbf{2}$, 28-33.

DeNicola, A. J., Weber, S. J., Bridges, C. A., and Stokes, J. L. (1997). Nontraditional techniques for management of overabundant deer populations. Wildife Society Bulletin 25, 496-499.

DeNicola, A. J., Vercauteren, K. C., Curtis, P. D., and Hygnstrom, S. E. (2000). 'Managing White-tailed Deer in Suburban Environments A Technical Guide.' (Cornell Cooperative Extension: Ithaca, NY.)

DeNicola, A. J., Etter, D. R., and Almendinger, T. (2008). Demographics of non-hunted white-tailed deer populations in suburban areas. Human-Wildlife Conflicts 2, 102-109.

Dexter, N. (1996). The effect of an intensive shooting exercise from a helicopter on the behaviour of surviving feral pigs. Wildlife Research 23, 435-441. doi:10.1071/WR9960435

Didier, K. A., and Porter, W. F. (1999). Large-scale assessment of potential habitat to restore elk to New York State. Wildlife Society Bulletin 27, 409-418.

Dieni, J. S., Smith, R. L., Rogers, R. L., and Anderson, S. H. (2000). Effects of ungulate browsing on aspen regeneration in northwestern Wyoming. Intermountain Journal of Sciences 6, 49-55.

Doenier, P. B., DelGiudice, G. D., and Riggs, M. R. (1997). Effects of winter supplemental feeding on browse consumption of white-tailed deer. Wildlife Society Bulletin 25, 235-243. 
Dolbeer, R. A. (1998). Population dynamics: the foundation of wildlife damage management for the 21 st century. Proceedings of the Vertebrate Pest Conference 18, 2-11.

Donovan, G., and Champ, P. (2009). The economic benefits of elk viewing at the Jewell Meadows Wildlife Area in Oregon. Human Dimensions of Wildlife 14, 51-60. doi:10.1080/10871200802545773

Edge, W. D., and Marcum, C. L. (1985). Movements of elk in relation to logging disturbances. The Journal of Wildlife Management 49, 926-930. doi: $10.2307 / 3801372$

Etter, R. P., and Drew, M. L. (2006). Brucellosis in elk of eastern Idaho. Journal of Wildlife Diseases 42, 271-278.

Fagerstone, K. A., and Clay, W. H. (1997). Overview of USDA animal damage control efforts to manage overabundant deer. Wildlife Society Bulletin 25, 413-417.

Fagerstone, K. A., Coffey, M. A., Curtis, P. D., Dolbeer, R. A., Killian, G. J., Miller, L. A., and Wilmot, L. M. (2002). Wildlife fertility control. The Wildlife Society Technical Review 02-2. The Wildlife Society, Bethesda, MD.

Fargione, M. J., Curtis, P. D., and Richmond, M. E. (1991). Resistance of woody ornamental plants to deer damage. Wildlife damage management program fact sheet. Cornell Cooperative Extension, Ithaca, NY.

Farnsworth, M. L., Wolfe, L. L., Hobbs, N. T., Burnham, K. P., Williams, E. S., Theobald, D. M., Conner, M. M., and Miller, M. W. (2005). Human land use influences chronic wasting disease prevalence in mule deer. Ecological Applications 15, 119-126. doi:10.1890/04-0194

Feldhamer, G. A., Gates, J. E., Harman, D. M., Loranger, A. J., and Dixon, K. R. (1986). Effects of interstate highway fencing on white-tailed deer activity. The Journal of Wildlife Management 50, 497-503. doi:10.2307/ 3801112

Frair, J. L., Merrill, E. H., Allen, J. R., and Boyce, M. S. (2007). Know thy enemy: experience affects elk translocation success in risky landscapes. The Journal of Wildlife Management 71, 541-554. doi:10.2193/2006-141

Fricke, K. A., Cover, M. A., Hygnstrom, S. E., Groepper, S. R., Genoways, H. H., Hams, K. M., and VerCauteren, K. C. (2008). Historic and recent distributions of elk in Nebraska. Great Plains Research 18, 189-204.

Frid, A., and Dill, L. (2002). Human-caused disturbance stimuli as a form of predation risk. Conservation Ecology 6, 1-11.

Gage, E., and Cooper, D. (2009). A study of the effectiveness of a fence design in excluding elk and moose but allowing the movement of other wildlife. Final Research Report, RM-CESU Cooperative Agreement Number H1200040001. Colorado State University, Fort Collins, CO.

Gehring, T. M., Vercauteren, K. C., and Landry, J. (2010). Livestock protection dogs in the 21st century: is an ancient tool relevant to modern conservation challenges? Bioscience 60, 299-308. doi:10.1525/ bio.2010.60.4.8

Gilsdorf, J. M., Hygnstrom, S. E., and VerCauteren, K. C. (2002). Use of frightening devices wildlife damage management. Integrated Pest Management Reviews 7, 29-45. doi:10.1023/A:1025760032566

Gilsdorf, J. M., Hygnstrom, S. E., VerCauteren, K. C., and Blankenship, E. E. $(2004 a)$. Propane exploders and electronic guards were ineffective at reducing deer damage in corn fields. Wildlife Society Bulletin 32, 524-531. doi:10.2193/0091-7648(2004)32[524:PEAEGW]2.0.CO;2

Gilsdorf, J. M., Hygnstrom, S. E., VerCauteren, K. C., Clements, G. M., Blankenship, E. E., and Engeman, R. M. (2004b). Evaluation of a deeractivated bio-acoustic frightening device for reducing deer damage in cornfields. Wildlife Society Bulletin 32, 515-523. doi:10.2193/0091-7648 (2004)32[515:EOADBF]2.0.CO;2

Goddard, P. J., Summers, R. W., Macdonald, A. J., Murray, C., and Fawcett, A. R. (2001). Behavioural responses of red deer to fences of five different designs. Applied Animal Behaviour Science 73, 289-298. doi:10.1016/ S0168-1591(01)00150-2

Green, J. S., and Woodruff, R. A. (1990). Livestock guarding dogs: protecting sheep from predators. Agriculture Information Bulletin, Number 588. Extension Service and Agricultural Research Service, Washington, DC.
Greer, K. R., Hawkins, W. W., and Catlin, J. E. (1968). Experimental studies of controlled reproduction in elk (Wapiti). The Journal of Wildlife Management 32, 368-376. doi:10.2307/3798982

Gross, J. A., and Knight, J. E. (2000). Elk presence inside various-sized cattle exclosures. Journal of Range Management 53, 287-290. doi:10.2307/ 4003433

Haggerty, J., and Travis, W. R. (2006). Out of administrative control: absentee owners, resident elk and the shifting nature of wildlife management in southwestern Montana. Geoforum 37, 816-830. doi:10.1016/j.geoforum. 2005.12.004

Hamir, A. N., Kunkle, R. A., Miller, J. M., Greenlee, J. J., and Richt, J. A. (2006). Experimental second passage of chronic wasting disease $\left(\mathrm{CWD}^{\text {mule deer }}\right)$ agent to cattle. Journal of Comparative Pathology 134, 63-69. doi:10.1016/j.jcpa.2005.07.001

Hams, K., and Trindle, B. (2008). Annual performance report: 2007-08. W-15-R, Segment 64. Nebraska Game and Parks Commission, Wildlife Division, Lincoln, NE.

Hansen, I., and Bakken, M. (1999). Livestock-guarding dogs in Norway: Part I. Interactions. Journal of Range Management 52, 2-6. doi:10.2307/ 4003485

Hansen, L., and Beringer, J. (1997). Managed hunts to control white-tailed deer populations on urban public areas in Missouri. Wildlife Society Bulletin 25, 484-487.

Hargreaves, S. K., Foggin, C. M., Anderson, E. C., Bastos, A. D. S., Thomson, G. R., Ferris, N. P., and Knowles, N. J. (2004). An investigation into the source and spread of foot and mouth disease virus from a wildlife conservancy in Zimbabwe. Revue Scientifique et Technique (International Office of Epizootics) 23, 783-790.

Harrington, J. L., and Conover, M. R. (2006). Characteristics of ungulate behavior and mortality associated with wire fences. Wildlife Society Bulletin 34, 1295-1305. doi:10.2193/0091-7648(2006)34[1295: COUBAM]2.0.CO;2

Harris, M. T., Palmer, W. L., and George, J. L. (1983). Preliminary screening of white-tailed deer repellents. The Journal of Wildlife Management 47, 516-519. doi:10.2307/3808526

Hebblewhite, M., and Merrill, E. H. (2009). Trade-offs between predation risk and forage differ between migrant strategies in a migratory ungulate. Ecology 90, 3445-3454. doi:10.1890/08-2090.1

Hebblewhite, M., and Pletscher, D. H. (2002). Effects of elk group size on predation by wolves. Canadian Journal of Zoology 80, 800-809. doi:10.1139/z02-059

Hebblewhite, M., Pletscher, D. H., and Paquet, P. C. (2002). Elk population dynamics in areas with and without predation by recolonizing wolves in Banff National Park, Alberta. Canadian Journal of Zoology 80, 789-799. doi:10.1139/z02-058

Hebblewhite, M., Merrill, E. H., Morgantini, L. E., White, C. A., Allen, J. R., Bruns, E., Thurston, L., and Hurd, T. E. (2006). Is the migratory behavior of montane elk herds in peril? The case of Alberta's Ya Ha Tinda elk herd. Wildlife Society Bulletin 34, 1280-1294. doi:10.2193/0091-7648(2006) 34[1280:ITMBOM]2.0.CO;2

Hegel, T. M., Gates, C. C., and Eslinger, D. (2009). The geography of conflict between elk and agricultural values in the Cypress Hills, Canada. Journal of Environmental Management 90, 222-235. doi:10.1016/j.jenvman. 2007.09.005

Henigman, J., Turner, J., and Swift, K. (2005). Roosevelt elk wildlife habitat decision aid. BC Journal of Ecosystems and Management $\mathbf{6}$, $51-53$.

Herner-Thogmartin, J. (1999). Ecology of an introduced Rocky Mountain elk (Cervus elaphus) herd in Arkansas. M.Sc. Thesis, University of Arkansas, Fayetteville, AR.

Hines, A. M., Ezenwa, V. O., Cross, P., and Rogerson, J. D. (2007). Effects of supplemental feeding on gastrointestinal parasite infection in elk (Cervus elaphus): preliminary observations. Veterinary Parasitology 148, 350-355. doi:10.1016/j.vetpar.2007.07.006 
Hofmann, R. R. (1988). Anatomy of the gastro-intestinal tract. In 'The Ruminant Animal: Digestive Physiology and Nutrition'. (Ed. D. C. Church.) pp. 14-43. (Prentice-Hall: Englewood Cliffs, NJ.)

Holdø, R. M., Dudley, J. P., and McDowell, L. R. (2002). Geophagy in the African elephant in relation to availability of dietary sodium. Journal of Mammalogy 83, 652-664. doi:10.1644/1545-1542(2002)083<0652: GITAEI $>2.0 . \mathrm{CO} ; 2$

Hone, J. (1990). Predator-prey theory and feral pig control, with emphasis on evaluation of shooting from a helicopter. Australian Wildlife Research 17, 123-130. doi:10.1071/WR9900123

Hygnstrom, S. E., and Craven, S. R. (1988). Electric fences and commercial repellents for reducing deer damage in cornfields. Wildlife Society Bulletin 16, 291-296.

Hygnstrom, S. E., Cover, M. A., Stillings, B. A., Crank, R. D., Fischer, J. W., Merchant, J. W., and Korte, S. P. (2005). Elk in Nebraska: opportunity or another private-public land conundrum. Proceedings of the Wildlife Damage Management Conference 11, 213-218.

Ishmael, W. E., and Rongstad, O. J. (1984). Economics of an urban deerremoval program. Wildlife Society Bulletin 12, 394-398.

Ishmael, W. E., Katsma, D. E., Isaac, A., and Bryant, B. K. (1995). Livecapture and translocation of suburban white-tailed deer in River Hills, Wisconsin. Proceedings of the Midwest Fish and Wildlife Conference $\mathbf{5 5}, 87-96$.

Jay, M. T., Cooley, M., Carychao, D., Wiscomb, G. W., Sweitzer, R. A., Crawford-Miksza, L., Farrar, J. A., Lau, D. K., O'Connell, J., Millington, A., Asmundson, R. V., Atwill, E. R., and Mandrell, R. E. (2007). Escherichia coli O157:H7 in feral swine near spinach fields and cattle, central California coast. Emerging Infectious Diseases 13, 1908-1911.

Jenkins, K. J., and Starkey, E. E. (1993). Winter forages and diets of elk in oldgrowth and regenerating coniferous forests in western Washington. American Midland Naturalist 130, 299-313. doi:10.2307/2426129

Johnson, T. L., and Monello, R. J. (2001). An adaptive approach to elk management in Rocky Mountain National Park. In 'Crossing Boundaries in Park Management: Proceedings of the Conference on Research and Resource Management in Parks and on Public Lands'. (Ed. D. Harmon.) pp. 82-86. (The George Wright Society: Hancock, MI.)

Jones, J. M., and Witham, J. H. (1990). Post-translocation survival and movements of metropolitan white-tailed deer. Wildlife Society Bulletin 18, 434-441.

Jordan, A. J., and Workman, J. P. (1989). Economics and management of fee hunting for deer and elk in Utah. Wildlife Society Bulletin 17, 482-487.

Kahler, K. E. (1991). Responsible strategies for wildlife control. Golf Course Management June, 72-80.

Karhu, R. R., and Anderson, S. H. (2006). The effect of high-tensile electric fence designs on big-game and livestock movements. Wildife Society Bulletin 34, 293-299. doi:10.2193/0091-7648(2006)34[293:TEOHEF] 2.0.CO; 2

Kay, C. E. (1994). Aboriginal overkill - the role of Native Americans in structuring western ecosystems. Human Nature 5, 359-398. doi:10.1007/ BF02734166

Kay, C. E. (1997). Viewpoint: ungulate herbivory, willows, and political ecology in Yellowstone. Journal of Range Management 50, 139-145. doi: $10.2307 / 4002370$

Kessler, K. K. (1995). Financial compensation for wildlife damage: a review of programs in North America. Great Plains Wildlife Damage Control Workshop Proceedings 12, 90

Killian, G., Eisemann, J., Wagner, D., Werner, J., Shaw, D., Engeman, R., and Miller, L. (2006). Safety and toxicity evaluation of GonaCon immunocontraceptive vaccine in white-tailed deer. Proceedings of the Vertebrate Pest Conference 22, 82-87.

Killian, G., Kreeger, T. J., Rhyan, J., Fagerstone, K., and Miller, L. (2009). Observations on the use of Gonacon ${ }^{\mathrm{TM}}$ in captive female elk (Cervus elaphus). Journal of Wildlife Diseases 45, 184-188.
Kilpatrick, H. J., Spohr, S. M., and Chasko, G. G. (1997). A controlled deer hunt on a state-owned coastal reserve in Connecticut: controversies, strategies, and results. Wildlife Society Bulletin 25, 451-456.

Kilpatrick, H. J., Spohr, S. M., and Lima, K. K. (2001). Effects of population reduction on home ranges of female white-tailed deer at high densities. Canadian Journal of Zoology 79, 949-954. doi:10.1139/cjz-79-6-949

Kilpatrick, A. M., Gillin, C. M., and Daszak, P. (2009). Wildlife-livestock conflict: the risk of pathogen transmission from bison to cattle outside Yellowstone National Park. Journal of Applied Ecology 46, 476-485. doi:10.1111/j.1365-2664.2008.01602.x

Kimball, B. A., and Nolte, D. L. (2006). Development of a new deer repellent for the protection of forest resources. Western Journal of Applied Forestry 21, 108-111.

Kimball, B. A., Nolte, D. L., and Perry, K. B. (2005). Hydrolyzed casein reduces browsing of trees and shrubs by white-tailed deer. HortScience 40, 1810-1814.

Kloppers, E. L., Clair, C. C., and Hurd, T. E. (2005). Predator-resembling aversive conditioning for managing habituated wildlife. Ecology and Society 10(1), 31. http://www.ecologyandsociety.org/vol10/iss1/art31/

Knight, R. R., and Mudge, M. R. (1967). Characteristics of some natural licks in the Sun River Area, Montana. The Journal of Wildlife Management 31, 293-299. doi:10.2307/3798319

Knight, J. E., Swensson, E. J., and Sherwood, H. (1997). Elk use of modified fence-crossing designs. Wildlife Society Bulletin 25, 819-822.

Knipling, E. F. (1959). Sterile-male method of population control. Science 130, 902-904. doi:10.1126/science.130.3380.902

Koehler, A. E., Marsh, R. E., and Salmon, T. P. (1990). Frightening methods and devices/stimuli to prevent mammal damage - A review. Proceedings of the Vertebrate Pest Conference 14, 168-173.

Larkin, J. L., Maehr, D. S., Cox, J. J., Bolin, D. C., and Wichrowski, M. W. (2003). Demographic characteristics of a reintroduced elk population in Kentucky. The Journal of Wildlife Management 67, 467-476. doi: $10.2307 / 3802704$

Larkin, J. L., Cox, J. J., Wichrowski, M. J., Dzialak, M. R., and Maehr, D. S. (2004). Influences on release site fidelity of translocated elk. Restoration Ecology 12, 97-105. doi:10.1111/j.1061-2971.2004.00231.x

Lauber, T. B., Brown, T. L., and Gore, M. L. (2004). Learning by doing: deer management in urban and suburban communities. Human Dimensions Research Unit Series No. 04-2. Cornell University, Ithaca, NY.

Lee, M. E., and Miller, R. (2003). Managing elk in the wildland-urban interface: attitudes of Flagstaff, Arizona, residents. Wildlife Society Bulletin 31, 185-191.

Lehnert, M. E., and Bissonette, J. A. (1997). Effectiveness of highway crosswalk structures at reducing deer-vehicle collisions. Wildlife Society Bulletin 25, 809-818.

Licht, D. S., Millspaugh, J. J., Kunkel, K. E., Kochanny, C. O., and Peterson, R. O. (2010). Using small populations of wolves for ecosystem restoration and stewardship. Bioscience 60, 147-153. doi:10.1525/ bio.2010.60.2.9

Long, W. M. (1989). Habitat manipulations to prevent elk damage to private rangelands. Proceedings of the Great Plains Wildlife Damage Control Workshop 9, 101-103.

Lovaas, A. L. (1973). A cooperative elk trapping program in Wind Cave National Park. Wildlife Society Bulletin 1, 93-100.

Loveridge, A. J., Reynolds, J. C., and Milner-Gulland, E. J. (2006). Does sport hunting benefit conservation? In 'Key Topics in Conservation Biology'. (Eds D. W. Macdonald and K. Service.) pp. 224-240. (Oxford University Press: Oxford, UK.)

Lubow, B. C., Singer, F. J., Johnson, T. L., and Bowden, D. C. (2002). Dynamics of interacting elk populations within and adjacent to Rocky Mountain National Park. The Journal of Wildlife Management 66, 757-775. doi: $10.2307 / 3803141$ 
MacLean, R. A., Mathews, N. E., Grove, D. M., Frank, E. S., and PaulMurphy, J. (2006). Surgical technique for tubal ligation in white-tailed deer (Odocoileus virginianus). Journal of Zoo and Wildlife Medicine 37, 354-360. doi:10.1638/05-091.1

Maehr, D. S., Grimes, R., and Larkin, J. L. (1999). Initiating elk restoration: the Kentucky case study. Proceedings of the Annual Conference of the Southeastern Association of Game and Fish Agencies 53, 350-363.

Malcolm, K. D., Van Deelen, T. R., Drake, D., Kesler, D. J., and VerCauteren, K. C. (2010). Contraceptive efficacy of a novel intrauterine device (IUD) in white-tailed deer. Animal Reproduction Science 117, 261-265. doi:10.1016/j.anireprosci.2009.05.003

Mason, R. J. (1998). Mammal repellants: options and considerations for development. Proceedings of the Vertebrate Pest Conference 18, 325-329.

Mauldin, R. E., and Miller, L. A. (2007). Wildlife contraception: targeting the oocyte. In 'Proceedings of an International Symposium on Managing Vertebrate Invasive Species'. (Eds G. W. Witmer, W. C. Pitt and K. A. Fagerstone.) pp. 434-444. (USDA/APHIS/WS National Wildlife Research Center: Fort Collins, CO.)

McCabe, R. E. (2002). Elk and Indians: then again. In 'North American Elk: Ecology and Management'. (Eds D. E. Toweill and J. W. Thomas.) pp. 121-197. (Smithsonian Institute Press: Washington, DC.)

McCorquodale, S. M. (1987). Fall-Winter habitat use by elk in the shrubsteppe of Washington. Northwest Science 61, 171-173.

McCorquodale, S. M. (1991). Energetic considerations and habitat quality for elk in arid grasslands and coniferous forests. The Journal of Wildlife Management 55, 237-242. doi:10.2307/3809145

McKenzie, J. A. (2001). The demographic and nutritional benefits of urban habitat use by elk. M.Sc. Thesis, University of Guelph, Ontario, Canada.

McKillop, I. G., and Sibly, R. M. (1988). Animal behaviour at electric fences and implications for management. Mammal Review 18, 91-103. doi:10.1111/j.1365-2907.1988.tb00078.x

Miller, L. A., Johns, B. E., Elias, D. J., and Killian, G. J. (1999). Oral vaccination of white-tailed deer using a recombinant Bacillus CalmetteGuerin vaccine expressing the Borrelia burgdorferi outer surface protein A: prospects for immunocontraception. American Journal of Reproductive Immunology 41, 279-285.

Miller, R., Kaneene, J. B., Fitzgerald, S. D., and Schmitt, S. M. (2003). Evaluation of the influence of supplemental feeding of white-tailed deer (Odocoileus virginianus) on the prevalence of bovine tuberculosis in the Michigan wild deer population. Journal of Wildlife Diseases 39, 84-95.

Miller, L. A., Gionfriddo, J. P., Fagerstone, K. A., Rhyan, J. C., and Killian, G. J. (2008). The single-shot GnRH immunocontraceptive vaccine (GonaCon) in white-tailed deer: comparison of several GnRH preparations. American Journal of Reproductive Immunology $\mathbf{6 0}$, 214-223. doi:10.1111/j.1600-0897.2008.00616.x

Miller, L. A., Fagerstone, K. A., Wagner, D. C., and Killian, G. J. (2009). Factors contributing to the success of a singl-shot, multiyear PZP immunocontraceptive vaccine for white-tailed deer. Human-Wildlife Conflicts 3, 103-115.

Morrison, J. R., de Vergie, W. J., Alldredge, A. W., Byrne, A. E., and Andree, W. W. (1995). The effects of ski area expansion on elk. Wildlife Society Bulletin 23, 481-489.

Mould, E. D., and Robbins, C. T. (1981). Nitrogen metabolism in elk. The Journal of Wildlife Management 45, 323-334. doi:10.2307/3807915

Mould, E. D., and Robbins, C. T. (1982). Digestive capabilities in elk compared to white-tailed deer. The Journal of Wildlife Management 46, 22-29. doi: $10.2307 / 3808404$

Muller-Schwarze, D. (1994). The senses of deer. In 'The Wildlife Series: Deer'. (Eds D. Gerlach, S. Atwater and J. Schnell.) pp. 58-665. (Stackpole Books: Mechanicsburg, PA.)

Neff, M. W. (2007). Scenario planning for wildlife management: a case study of the National Elk Refuge, Jackson, Wyoming. Human Dimensions of Wildlife 12, 219-226. doi:10.1080/10871200701442783
Nolte, D. L. (1998). Efficacy of selected repellents to deter deer browsing on conifer seedlings. International Biodeterioration \& Biodegradation 42 , 101-107. doi:10.1016/S0964-8305(98)00008-0

Nolte, D. (1999). Behavioral approaches for limiting depredation by wild ungulates. In 'Grazing Behavior of Livestock and Wildlife'. (Eds K. L. Launchbaugh, K. D. Sanders and J. C. Mosley.) pp. 60-69. Idaho Forest, Wildlife \& Range Experimental Station Bulletin \#70. (University of Idaho: Moscow, ID.)

Nolte, D. L., Farley, J. P., and Holbrook, S. (1995). Effectiveness of BGR-P and garlic in inhibiting browsing of western redcedar by black-tailed deer. Tree Planters' Notes 46, 23-27.

Nolte, D. L., Shipley, L. A., and Wagner, K. K. (2001). Efficacy of Wolfin to repel black-tailed deer. Western Journal of Applied Forestry 16, 182-186.

Nolte, D. L., VerCauteren, K. C., Perry, K. R., and Adams, S. E. (2003). Training deer to avoid sites through negative reinforcement. Proceedings of the Wildlife Damage Management Conference 10, 95-104.

Nugent, G., and Choquenot, D. (2004). Comparing cost-effectiveness of commercial harvesting, state-funded culling, and recreational deer hunting in New Zealand. Wildlife Society Bulletin 32, 481-492. doi:10.2193/0091-7648(2004)32[481:CCOCHS]2.0.CO;2

Nugent, G., Fraser, K. W., Asher, G. W., and Tustin, K. G. (2001). Advances in New Zealand mammalogy 1990-2000: deer. Journal of the Royal Society of New Zealand 31, 263-298. doi:10.1080/03014223.2001. 9517654

O’Bryan, M. K., and McCullough, D. R. (1985). Survival of black-tailed deer following relocation in California. The Journal of Wildlife Management 49, 115-119. doi:10.2307/3801854

O'Gara, B. W., and Dundas, R. G. (2002). Distribution: past and present. In 'North American Elk: Ecology and Management'. (Eds D. E. Toweill and J. W. Thomas.) pp. 67-119. (Smithsonian Institute Press: Washington, DC.)

Oldenburg, L. E. (1984). Idaho elk population status/depredation problems. In 'Western States Elk Workshop'. (Ed. R. W. Nelson.) pp. 75-79. (Western Association of Fish and Wildlife Agencies and Alberta Fish and Wildlife Division: Edmonton, Alberta.)

Palmer, W. L., Wingard, R. G., and George, J. L. (1983). Evaluation of whitetailed deer repellents. Wildlife Society Bulletin 11, 164-166.

Parkes, J. P., Nugent, G., and Warburton, B. (1996). Commercial exploitation as a pest control tool for introduced mammals in New Zealand. Wildlife Biology 2, 171-177.

Peek, J. M., Schmidt, K. T., Dorrance, M. J., and Smith, B. L. (2002). Supplemental feeding and farming of elk. In 'North American Elk: Ecology and Management'. (Eds D. E. Toweill and J. W. Thomas.) pp. 617-647. (Smithsonian Institute Press: Washington, DC.)

Peinetti, H. R., Kalkhan, M. A., and Coughenour, M. B. (2002). Long-term changes in willow spatial distribution on the elk winter range of Rocky Mountain National Park (USA). Landscape Ecology 17, 341-354. doi:10.1023/A:1020530710891

Peterson, M. N., Lopez, R. R., Silvy, N. J., Owen, C. B., Frank, P. A., and Braden, A. W. (2003). Evaluation of deer-exclusion grates in urban areas. Wildlife Society Bulletin 31, 1198-1204.

Phillips, G. E., and Alldregde, A. W. (2000). Reproductive success of elk following disturbance by humans during calving season. The Journal of Wildlife Management 64, 521-530. doi:10.2307/3803250

Plumb, G. E., White, P. J., Coughenour, M. B., and Wallen, R. L. (2009). Carrying capacity, migration, and dispersal in Yellowstone bison. Biological Conservation 142, 2377-2387. doi:10.1016/j.biocon.2009. 05.019

Porter, W. F. (1983). A baited electric fence for controlling deer damage to orchard seedlings. Wildlife Society Bulletin 11, 325-327.

Putman, R. J., and Staines, B. W. (2004). Supplementary winter feeding of wild red deer Cervus elaphus in Europe and North America: justifications, feeding practice and effectiveness. Mammal Review 34, 285-306. doi:10.1111/j.1365-2907.2004.00044.x 
Ramsey, C. W. (1968). A drop-net deer trap. The Journal of Wildlife Management 32, 187-190. doi:10.2307/3798257

Ramsey, K. J., and Krueger, W. C. (1986). Grass-legume seeding to improve winter forage for Roosevelt elk: a literature review. Agricultural Experiment Station Special Report 763. Oregon State University, Corvallis, OR.

Relyea, R. A., Lawrence, R. K., and Demarais, S. (2000). Home range of desert mule deer: testing the body-size and habitat-productivity hypotheses. The Journal of Wildlife Management 64, 146-153. doi:10.2307/3802984

Rigg, R. (2001). Livestock guarding dogs: their current use world wide. Canid Specialist Group Occassional Paper No. 1. Available at http://www. canids.org/occasionalpapers/ [accessed 17 January 2010].

Ripple, W. J., and Beschta, R. L. (2003). Wolf reintroduction, predation risk and cottonwood recovery in Yellowstone National Park. Forest Ecology and Management 184, 299-313. doi:10.1016/S0378-1127(03)00154-3

Roper, R. B., and Hill, E. P. (1985). An evaluation of visual and auditory electronic devices to repel deer. Proceedings of the Eastern Wildlife Damage Control Conference 2, 186-191.

Rosatte, R., Hamr, J., Young, J., Filion, I., and Smith, H. (2007). The restoration of elk (Cervus elaphus) in Ontario, Canada: 1998-2005. Restoration Ecology 15, 34-43. doi:10.1111/j.1526-100X.2006.00187.x

Rowland, M. M., Wisdom, M. J., Johnson, B. K., and Kie, J. G. (2000). Elk distribution and modeling in relation to roads. The Journal of Wildlife Management 64, 672-684. doi:10.2307/3802737

Rubin, E. S., Boyce, W. M., Stermer, C. J., and Torres, S. G. (2002). Bighorn sheep habitat use and selection near an urban environment. Biological Conservation 104, 251-263. doi:10.1016/S0006-3207(01)00171-9

Rutberg, A. T., Naugle, R. E., Thiele, L. A., and Liu, I. K. M. (2004). Effects of immunocontraception on a suburban population of white-tailed deer Odocoileus virginianus. Biological Conservation 116, 243-250. doi:10.1016/S0006-3207(03)00195-2

Sayre, R. W., and Richmond, M. E. (1992). Evaluation of a new deer repellent on Japanese yews at suburban homesites. Proceedings of the Eastern Wildlife Damage Control Conference 5, 38-93.

Schemnitz, S. D. (1994). Capturing and handling wild animals. In 'Research and Management Techniques for Wildlife and Habitats'. (Ed. T. A. Bookhout.) pp. 106-124. (The Wildlife Society: Bethesda, MD.)

Schneidmiller, J. F. (1987). Fencing methods to control big game damage to stored crops in Wyoming. Proceedings of the Great Plains Wildlife Damage Control Workshop 8, 217-221.

Schoenecker, K. A., Singer, F. J., Zeigenfuss, L. C., Binkley, D., and Menezes, R. S. C. (2004). Effects of elk herbivory on vegetation and nitrogen processes. The Journal of Wildife Management 68, 837-849. doi:10.2193/0022-541X(2004)068[0837:EOEHOV]2.0.CO;2

Schultz, R. D., and Bailey, J. A. (1978). Responses of National Park elk to human activity. The Journal of Wildlife Management 42, 91-100. doi: $10.2307 / 3800694$

Scott, M. D. (1992). Buck-and-pole fence crossings by 4 ungulate species. Wildlife Society Bulletin 20, 204-210.

Seamans, T. W., and Helon, D. A. (2008). Comparison of electrified mats and cattle guards to control white-tailed deer (Odocoileus virginianus) access through fences. Proceedings of the Vertebrate Pest Conference 23, 206-209.

Seamans, T. W., Blackwell, B. F., and Cepek, J. D. (2002). Coyote hair as an area repellent for white-tailed deer. International Journal of Pest Management 48, 301-306. doi:10.1080/09670870210149853

Seward, N. W., Phillips, G. E., Duquette, J. F., and Vercauteren, K. C. (2007). A frightening device for deterring deer use of cattle feeders. The Journal of Wildlife Management 71, 271-276. doi:10.2193/2006-265

Shively, K. J., Alldregde, A. W., and Phillips, G. E. (2005). Elk reproductive response to removal of calving season disturbance by humans. The Journal of Wildlife Management 69, 1073-1080. doi:10.2193/0022541X(2005)069[1073:ERRTRO]2.0.CO;2
Shivik, J. A., and Martin, D. J. (2000). Aversive and disruptive stimulus applications for managing predation. Proceedings of the Wildlife Damage Management Conference 9, 111-119.

Short, H. L., Dietz, D. R., and Remmenga, E. E. (1966). Selected nutrients in mule deer browse plants. Ecology 47, 222-229. doi:10.2307/1933768

Skovlin, J. M., Edgerton, P. J., and McConnell, B. R. (1983). Elk use of winter range as affected by cattle grazing, fertilizing, and burning in southeastern Washington. Journal of Range Management 36, 184-189. doi:10.2307/ 3898159

Smith, B. L. (2001). Winter feeding of elk in western North America. The Journal of Wildlife Management 65, 173-190. doi:10.2307/3802896

Smith, R. H., Neff, D. J., and Woolsey, N. G. (1986). Pronghorn response to coyote control: a benefit: cost analysis. Wildlife Society Bulletin 14, 226-231.

Spalinger, D. E., Cooper, S. M., Martin, D. J., and Shipley, L. A. (1997). Is social learning an important influence on foraging behavior in white-tailed deer? The Journal of Wildlife Management 61, 611-621. doi:10.2307/ 3802169

St Clair, C. C., and Forrest, A. (2009). Impacts of vehicle traffic on the distribution and behaviour of rutting elk, Cervus elaphus. Behaviour 146, 393-413. doi:10.1163/156853909X410973

Stewart, S. C., Fix, P. J., and Manfredo, M. J. (2004). Public perceptions of elk and vegetation management in Rocky Mountain National Park, Colorado. Rocky Mountain National Park Project Report No. 56. Colorado State University, Fort Collins, CO.

Stockstad, D. S., Morris, M. S., and Lory, E. C. (1953). Chemical characteristics of natural licks used by big game animals in western Montana. Transactions of the North American Wildlife Conference 18, 247-257.

Storlie, J. T. (2006). Movements and habitat use of female Roosevelt elk in relation to human disturbance on the Hoko and Dickey Game Management Units, Washington. M.Sc. Thesis, Humbolt State University, Arcata, CA.

Stout, G. G., Lowry, F. C., and Carlisle, F. (1972). The status of elk transplants in eastern Oklahoma. Proceedings of the Annual Conference of the Southeastern Association of Game and Fish Agencies 26, 202-203.

Suzuki, K., Suzuki, H., Binkley, D., and Stohlgren, T. J. (1999). Aspen regeneration in the Colorado Front Range: differences at local and landscape scales. Landscape Ecology 14, 231-237. doi:10.1023/ A: 1008062514060

Swihart, R. K., and Conover, M. R. (1990). Reducing deer damage to yews and apple trees: testing Big Game Repellent ${ }^{\circledR}, \operatorname{RoPel}^{\circledR}$ and soap as repellents. Wildlife Society Bulletin 18, 156-162.

Swihart, R. K., Pignatello, V., Mattina, M. J. I., and Tennessen, M. (1991). Aversive responses of white-tailed deer, Odocoileus virginianus, to predator urines. Journal of Chemical Ecology 17, 767-777. doi:10.1007/BF00994199

Taylor, T. S., Loewenstein, E. F., and Chappelka, A. H. (2006). Effect of animal browse protection and fertilizer application on the establishment of planted Nuttall oak seedlings. New Forests 32, 133-143. doi:10.1007/ s11056-005-4167-3

Thompson, M. J., and Henderson, R. E. (1998). Elk habituation as a credibility challenge for wildlife professionals. Wildlife Society Bulletin 26, 477-483.

Thompson, M. J., Henderson, R. E., Lemke, T. O., and Sterling, B. A. (1989). Evaluation of a collapsible clover trap for elk. Wildlife Society Bulletin 17, 287-290

Trombulak, S. C., and Frissell, C. A. (2000). Review of ecological effects of roads on terrestrial and aquatic communities. Conservation Biology 14, 18-30. doi:10.1046/j.1523-1739.2000.99084.x

Tufto, J., Andersen, R., and Linnell, J. (1996). Habitat use and ecological correlates of home range size in a small cervid: the roe deer. Journal of Animal Ecology 65, 715-724. doi:10.2307/5670 
Van Deelen, T. R. (2003). Chronic wasting disease and the science in support of the ban on baiting and feeding deer. Available at http://www.dnr.state. wi.us/org/land/wildlife/Whealth/issues/Cwd/doc/cwdscsu.pdf [accessed 12 April 2007].

Van Deelen, T. R., McKinney, L. B., Joselyn, M. G., and Buhnerkempe, J. E. (1997). Can we restore elk to southern Illinois? The use of existing digital land-cover data to evaluate potential habitat. Wildife Society Bulletin 25, 886-894.

Van Tassell, L. W., Phillips, C., and Yang, B. (1999). Depredation claim settlements in Wyoming. Wildlife Society Bulletin 27, 479-487.

VerCauteren, K. C., and Pipas, M. J. (2003). A review of color vision in whitetailed deer. Wildlife Society Bulletin 31, 684-691.

VerCauteren, K. C., Beringer, J., and Hygnstrom, S. E. (1997). Use of nettedcage traps in population management and research of urban white-tailed deer. Proceedings of the Great Plains Wildlife Damage Control Workshop 13, 138-142.

VerCauteren, K. C., Hygnstrom, S. E., Pipas, M. J., Fioranelli, P. B., Werner, S. J., and Blackwell, B. F. (2003). Red lasers are ineffective for dispersing deer at night. Wildlife Society Bulletin 31, 247-252.

VerCauteren, K. C., Seward, N. W., Hirchert, D. L., Jones, M. L., and Beckerman, S. F. (2005a). Dogs for reducing wildlife damage to organic crops: a case study. Proceedings of the Wildlife Damage Management Conference 11, 286-293.

VerCauteren, K. C., Shivik, J. A., and Lavelle, M. J. (2005b). Efficacy of an animal-activated frightening device on urban elk and mule deer. Wildlife Society Bulletin 33, 1282-1287. doi:10.2193/0091-7648(2005)33[1282: EOAAFD]2.0.CO;2

VerCauteren, K. C., Gilsdorf, J. M., Hygnstrom, S. E., Fioranelli, P. B., Wilson, J. A., and Barras, S. (2006a). Green and blue lasers are ineffective for dispersing deer at night. Wildlife Society Bulletin 34, 371-374. doi:10.2193/0091-7648(2006)34[371:GABLAI]2.0.CO;2

VerCauteren, K. C., Lavelle, M. J., and Hygnstrom, S. E. (2006b). Fences and deer-damage management: a review of designs and efficacy. Wildlife Society Bulletin 34, 191-200. doi:10.2193/0091-7648(2006)34[191: FADMAR]2.0.CO;2

VerCauteren, K. C., Lavelle, M. J., and Hygnstrom, S. E. (2006c). A simulation model for determining cost-effectiveness of fences for reducing deer damage. Wildlife Society Bulletin 34, 16-22. doi:10.2193/0091-7648(2006)34[16:ASMFDC]2.0.CO;2

VerCauteren, K. C., Lavelle, M. J., Seward, N. W., Fischer, J. W., and Phillips, G. E. $(2007 a)$. Fence-line contact between wild and farmed cervids in Colorado: potential for disease transmission. The Journal of Wildlife Management 71, 1594-1602. doi:10.2193/2006-178

VerCauteren, K. C., Seward, N. W., Lavelle, M. J., Fischer, J. W., and Phillips, G. E. (2007b). A fence design for excluding elk without impeding other wild life. Rangeland Ecology and Management 60,529-532. doi:10.2111/ 1551-5028(2007)60[529:AFDFEE]2.0.CO;2

VerCauteren, K. C., Lavelle, M. J., and Phillips, G. E. (2008). Livestock protection dogs for deterring deer from cattle and feed. The Journal of Wildlife Management 72, 1443-1448. doi:10.2193/2007-372
VerCauteren, K. C., Seward, N. W., Lavelle, M. J., Fischer, J. W., and Phillips, G. E. (2009). Deer guards and bump gates for excluding white-tailed deer from fenced resources. Human-Wildlife Conflicts 3, 145-153.

Vieira, M. E. P., Conner, M. M., White, G. C., and Freddy, D. J. (2003). Effects of archery hunter numbers and opening dates on elk movement. The Journal of Wildlife Management 67, 717-728. doi:10.2307/3802678

Wagner, K. K., Schmidt, R. H., and Conover, M. R. (1997). Compensation programs for wildlife damage in North America. Wildlife Society Bulletin $\mathbf{2 5}, 312-319$

Walter, W. D., and Leslie, D. M. Jr (2002). Harvest strategies and numbers of elk (Cervus elaphus) in Oklahoma, 1987-2001. Proceedings of the Oklahoma Academy of Science 82, 89-94.

Walter, W. D., Pekins, P. J., Rutberg, A. T., and Kilpatrick, H. J. (2002). Evaluation of immunocontraception in suburban white-tailed deer. Wildlife Society Bulletin 30, 186-192.

Walter, W. D., Leslie, D. M. Jr, and Jenks, J. A. (2006). Response of Rocky Mountain elk (Cervus elaphus) to wind-power development. American Midland Naturalist 156, 363-375. doi:10.1674/0003-0031(2006)156 [363:RORMEC]2.0.CO;2

Ward, A. L. (1982). Mule deer behavior in relation to fencing and underpasses on Interstate 80 in Wyoming. Transportation Research Record 859, $8-13$.

Washington Department of Fish and Wildlife (2009). 2009 game status and trend report. Wildlife Program, Washington Department of Fish and Wildlife, Olympia, WA.

White, C. A., Olmsted, C. E., and Kay, C. E. (1998). Aspen, elk and fire in the Rocky Mountain National Parks of North America. Wildlife Society Bulletin 26, 449-462.

Whyte, I. J., and Joubert, S. C. J. (1988). Blue wildebeest population trends in the Kruger National Park and the effects of fencing. South African Journal of Wildlife Research 18, 78-87.

Williams, T. R. (1962). The significance of salt and natural licks in elk management. M.Sc. Thesis, University of Idaho, Moscow, ID.

Wilson, C. J., Britton, A. M., and Symes, R. G. (2009). An assessment of agricultural damage caused by red deer (Cervus elaphus L.) and fallow deer (Dama dama L.) in southwest England. Wildlife Biology in Practice 5, 104-114. doi:10.2461/wbp.2009.5.11

Witham, J. (1996). Teaching elk to jump. Wildlife Views November, 17-19.

Witmer, G. W. (1998). When deer are too dear and elk are too elegant. The Probe 189, 1-5.

Witmer, G. W., and Cogan, R. (1989). Elk and crop damage in Pennsylvania. Proceedings of the Eastern Wildlife Damage Control Conference 4, 220-224.

Woodruff, R. A., and Green, J. S. (1995). Livestock herding dogs: a unigue application for wildlife damage management. Proceedings of the Great Plains Wildlife Damage Control Workshop 12, 43-45.

Manuscript received 11 February 2010, accepted 16 September 2010 